\title{
Pontes de transição entre direito e política: sentenças aditivas na experiência recente do STF
}

\author{
Ademar Borges de Sousa Filho
}

Advogado. Procurador do Município de Belo Horizonte. Mestre em Direito Constitucional pela UFF. Doutorando em Direito Público pela UERJ. Colaborador da Clínica de Direitos Fundamentais da UERJ. Membro do Centro Brasileiro de Estudos Constitucionais - CBEC.

\section{Resumo}

O Supremo Tribunal Federal demonstra, nos últimos anos, por meio da utilização da técnica decisória conhecida como aditiva, dispor de competência tipicamente normativa. A criação de direito novo pelo STF, entretanto, deve prestigiar ao máximo a esfera de competência do legislador, fazendo do controle de constitucionalidade um efetivo meio de diálogo institucional, cuja qualidade depende, em grande medida, da correção das técnicas decisórias utilizadas, especialmente das sentenças aditivas, campo no qual a possibilidade de concorrência no exercício de função normativa tem potencial para aperfeiçoar as condições de realização da democracia e a efetividade dos direitos fundamentais. A atividade normativa desempenhada pelo Judiciário não deve ser interpretada como interdição da competência do Congresso Nacional para regulamentar, a qualquer momento - e até mesmo de forma diversa -, o setor normativo que padecia de omissão legislativa. O objetivo da Corte constitucional ao exercitar essa competência normativa é iniciar um diálogo explícito com os poderes Executivo e Legislativo acerca da regulamentação de direitos fundamentais. Defende-se, neste trabalho, uma proposta de legitimação do uso moderado da função normativa judicial pelo STF como forma de aperfeiçoar o diálogo institucional com o Parlamento, de modo a promover, por meio da edição de sentenças aditivas, um verdadeiro diálogo institucional, não de forma abstrata ou retórica, mas sim em torno de medidas efetivas para o restabelecimento da normatividade constitucional violada.

\section{Palavras-chave}

Jurisdição Constitucional; Competência Judicial Normativa; Sentenças Aditivas; Diálogos Institucionais; Direitos Fundamentais. 


\title{
Transition bonds between law and politics: the additive rulings in Federal Supreme Court recent experience
}

\begin{abstract}
The Federal Supreme Court proves, in recent years, through the use of a deliberating technique known as additive, to have a typically regulatory competence. However, the creation of a new law by the Federal Supreme Court should honor to the full extent the scope of competence of the legislator, making the constitutionality control an effective means of institutional dialogue, whose quality depends to a great extent on the correction of decision-making techniques used, especially of additive rulings, a field in which the possibility of competition in the exercise of regulatory function has the potential to improve the conditions for the execution of democracy and effectiveness of fundamental rights. The regulatory activity performed by the Judiciary should not be construed as a prohibition of the competence of the National Congress to regulate, at any time - and even in a different way - the regulatory sector that suffered from legislative failure. The purpose of the constitutional Court when exercising such regulatory competence is to start an explicit dialogue with the Executive and Legislative branches about the regulation of fundamental rights. This study aims to support a proposal of legitimation of moderate use of the regulatory judicial function by the Federal Supreme Court as a way to improve the institutional dialogue with Parliament, in order to promote, through the issue of additive rulings, a real institutional dialogue, not abstractly or rhetorically, but rather, by addressing effective measures to re-establish the constitutional rules violated.
\end{abstract}

\section{Keywords}

Constitutional Jurisdiction; Regulatory Judicial Competence; Additive Rulings; Institutional Dialogues; Fundamental Rights.

\section{Sumário}

Introdução; 1 . O constitucionalismo como solução dinâmica ao problema da relação entre política e direito; 1.1. Constitucionalismo moderno: um movimento contra a subordinação política do direito; 1.2. O avanço do controle jurisdicional de constitucionalidade: surgimento recente do risco de subordinação da política ao direito; 1.3. A necessidade de reforçar a capacidade de aprendizado recíproco entre as esferas do direito e da política; 2. O Supremo Tribunal Federal como mediador da conversação entre direito e política; 2.1.Um mediador posicionado em um dos lados: necessidade de avaliação crítica das capacidades institucionais dos órgãos judiciais em face dos órgãos legislativos e executivos; 2.2. Os riscos de um mediador autista: os monólogos constitucionais do Supremo Tribunal Federal; 2.3. Diálogos institucionais e aprendizado recíproco: uma preocupação recente do STF; 3. Construindo "pontes de transição" entre direito e política por meio da jurisdição constitucional; 3.1. A escolha das técnicas decisórias na jurisdição constitucional a partir dos interlocutores preferenciais do STF: um modelo incentivador do 
diálogo; 3.2. Uma recente "ponte de transição" engendrada pelo STF: as sentenças aditivas como mecanismo de aperfeiçoamento do diálogo entre direito e política Conclusão; Bibliografia.

\section{Introdução}

O constitucionalismo moderno caracteriza-se pela pretensão de colocar em pé de igualdade direito e política. Acreditamos, desde o limiar da modernidade até os dias atuais, na política como modo legítimo de produção de direito e imputamos a este a função de limitar aquela. É a conhecida tensão entre liberdade dos antigos e liberdade dos modernos, entre proteção de direitos fundamentais e soberania popular e, enfim, entre constitucionalismo e democracia.

Se a modernidade buscava soluções para garantir a autonomia do direito em face da política, atualmente o constitucionalismo contemporâneo exige mais: além de evitar invasões totais da esfera política na jurídica, deve cuidar para que o contrário não aconteça, assim como também aperfeiçoar a comunicação entre essas esferas, fortalecendo a autonomia de cada uma e, ao mesmo tempo, incrementando a capacidade de aprendizagem recíproca. Em outras palavras, deve garantir que o direito sobreviva à política e que a política sobreviva ao direito, não pela estratégia do isolamento - que pode levar à morte por inanição -, mas pela abertura às influências recíprocas que animem tanto a política como o direito a realizarem de modo cooperativo os objetivos da nossa Constituição.

A tarefa do constitucionalismo contemporâneo passa necessariamente por assegurar um equilíbrio possível entre direito e política, entre direitos fundamentais e soberania popular, entre o ideal do constitucionalismo e o ideal democrático. Embora não haja necessária conexão entre constitucionalismo e jurisdição constitucional, sabe-se que a maioria dos países que vivenciam atualmente experiências constitucionais adotaram mecanismos de controle judicial da constitucionalidade das leis ${ }^{1}$. Nesses países, portanto,

${ }^{1}$ Sobre o tema, Dieter Grimm afirma: "A jurisdição constitucional não é nem incompatível nem indispensável à democracia. Aqueles que esposam uma posição contrária e declaram que a jurisdição constitucional é uma condição necessária à democracia argumentam que as constituições democráticas guardam pouco ou nenhum valor se não forem resguardadas por uma instituição que garanta que o governo irá cumprir as disposições constitucionais. (...) por outro lado, há suficientes provas históricas de que um estado democrático pode dispensar o controle judicial de constitucionalidade. As constituições não estão condenadas a permanecer como meros tigres de papel se não houver órgãos especializados para garantir a sua aplicação. É que há menos exemplos dessa última afirmação do que da assertiva contrária, mas indubitavelmente existem exemplos nesse sentido. Ninguém duvidaria do caráter democrático de Estados como o Reino Unido e a Holanda, que não adotam o controle judicial de constitucionalidade". Em outra publicação, Dieter 
cabe às Cortes constitucionais contribuir para o aprimoramento da comunicação entre direito e política, potencializando a capacidade de contribuição mútua para a realização do empreendimento democrático comum.

No Brasil, o Supremo Tribunal Federal, outrora acusado de não cumprir de forma adequada a tarefa de garantidor dos direitos fundamentais e das condições democráticas ${ }^{2}$, hoje recebe críticas por ter trocado - ainda que esporadicamente - a timidez pela ousadia, a passividade pela proatividade, a contenção pelo ativismo. Sem sequer superar todos os riscos estruturais de invasão da política no direito - ainda hoje não é raro encontrar tristes episódios de corrupção da autonomia da esfera jurídica por influências indesejadas da política na tomada de decisões estatais -, fala-se, pela primeira vez na história do constitucionalismo brasileiro, no risco de uma invasão do direito na política. Suspeita-se que o STF esteja, ainda que não de forma generalizada, fazendo escolhas que, sob a roupagem do direito, caberiam à política. O debate a propósito da legitimidade da jurisdição constitucional, vastamente reproduzido no Brasil nas últimas duas décadas, pode não ser suficiente para dar respostas concretas sobre o modo como o STF deve atuar, por meio de suas decisões, a fim de garantir a autonomia das esferas da política e do direito e construir entre elas "pontes de transição" capazes de gerar espaços de cooperação mútua e aprendizado recíproco. O presente estudo tem por objetivo lançar as bases de uma proposta de revisitação das técnicas decisórias do STF à luz da pretensão normativa de criação de formas concretas de comunicação construtiva entre as esferas do direito e da política.

Grimm afirma que "Tribunais constitucionais mostraram-se como instrumento especialmente efetivo de tal controle do poder e, por isso, tiveram, nesse meio tempo, reconhecimento internacional" (2006, p. 169).

2 Essa postura de inicial timidez do STF no liminar da nova Constituição não foge à regra. Como adverte Rodrigo Brandão: "De fato, Ginsburg constatou que no início de um regime constitucional sobretudo em novas democracias - há maior risco de ataques institucionais, de retaliações ao Judiciário ou de descumprimento de decisões judiciais, pois a Corte ainda não teve tempo para construir uma imagem de neutralidade política que a blindasse de tais ameaças. Precisamente para construir essa couraça, a Suprema Corte tende a se pautar por postura autorrestritiva nos seus primeiros anos de vida, afastando-se da aplicação de princípios abstratos a questões politicamente relevantes em favor de um maior formalismo na aplicação do Direito. Assim, para expandir o seu poder a Corte deve avançar devagar" (2015, p. 1477). 


\section{O constitucionalismo como solução dinâmica ao problema}

\section{da relação entre política e direito}

As relações entre política e direito foram profundamente alteradas com o advento do constitucionalismo moderno. Nas formas pré-modernas de organização social, assim como no absolutismo do início da modernidade, o direito estava subordinado à política ${ }^{3}$. Essa colonização pela política explica-se pelo fato de que o detentor do poder - tanto na prémodernidade como no nascimento da modernidade - não estava subordinado ao direito. Não se poderia cogitar da distinção entre lícito e ilícito para o detentor do poder, mas apenas para os súditos que estavam no polo inferior da relação de poder com o Estado. Embora o absolutismo tenha marcado a desvinculação parcial da criação do direito e da origem divina do poder $^{4}$, persistia uma relação assimétrica entre soberano e súdito, da qual resultava a sobreposição do poder político sobre o direito ${ }^{5}$. A passagem da prémodernidade para a modernidade implicou a superação de uma indiferenciação do poder e do direito - ambos confundiam-se na semântica religiosa que amparava a estrutura de dominação dos inferiores pelos superiores - por uma diferenciação baseada na subordinação do direito à política. A criação do direito pelo Estado - não mais vinculada ao direito sacro - não impediu que, no nascimento da modernidade, o poder político do monarca estivesse livre de limitações normativas ${ }^{6}$.

O elevado grau de complexidade da sociedade, marcada por diversas cosmovisões, já não suportava no plano estrutural a impossibilidade de oposição ao soberano, o que

\footnotetext{
${ }^{3}$ Marcelo Neves afirma que "não havia limitações jurídico-positivas relevantes ao soberano no exercício do jus imperium, ou seja, limitações normativas estabelecidas e impostos por outros homens à sua ação coercitiva" (2009, p. 9).

${ }^{4} \mathrm{~A}$ juridificação das relações horizontais entre privados, chamada por Marcelo Neves de "primeira fornada de juridificação", não importava direitos subjetivos acionáveis contra o soberano.

${ }^{5} \mathrm{~A}$ tendência à superação dos fundamentos sacros do poder e o surgimento da semântica do direito natural não impediram a instrumentalização política do direito pelo monarca absolutista. Dieter Grimm lembra que "o estado [absoluto], cujo mais importante atributo era a soberania, entendida desde o estudo de referência de Bodin como o direito do governante de ditar a lei para todos sem estar, ele mesmo, limitado por ela. O Estado surge como um Estado absoluto" (2014, p. 54).

${ }^{6}$ Como afirma Marcelo Neves, as decisões do detentor do poder "não são avaliadas de acordo com o código jurídico, mas antes pressupostas como intrinsecamente lícitas". Por isso que "no período absolutista tinha uma relevância especial o princípio 'Princeps legibus solutus est' ('o príncipe está isento da lei')" (2010. p. 205). Mantiveram-se indiferenciadas as esferas da política e do direito enquanto permaneceu vigente a compreensão de que as decisões dos detentores do poder não poderiam ser avaliadas de acordo com o código jurídico. Se o exercício do poder político era pressuposto como intrinsecamente lícito, então a política confundia-se com o direito numa mistura que impedia o controle normativo do poder estatal. O processo de diferenciação entre política e direito - iniciado no absolutismo mas inacabado por força da intensa subordinação daquela a este no campo da relação do indivíduo com o soberano - toma corpo a partir do período revolucionário do final do século XVIII.
} 
conduziu aos movimentos revolucionários de inspiração burguesa7 . Esse incremento de complexidade social fez eclodir um amplo processo de diferenciação sistêmico-funcional (novas esferas de comunicação social dotadas de autonomia, de racionalidade própria e com potencial para serem confrontadas umas pelas outras): sistema econômico (orientado pelo código ter/não ter), sistema político (norteado pelo código poder/não poder), sistema jurídico (guiado pelo código lícito/ilícito), sistema científico (orientado pelo código verdadeiro/falso), etc. Essa pluralidade de esferas de comunicação com pretensão de autonomia - característica da sociedade moderna - "estaria condenada à própria autodestruição, caso não desenvolvesse mecanismos que possibilitassem vínculos construtivos de aprendizado e influência recíproca entre as diversas esferas sociais" ${ }^{\prime 2}$. A sociedade moderna, após as revoluções burguesas, exigia a construção de mecanismos que viabilizassem, a um só tempo, a garantia de autonomia desses sistemas criados pelo aumento da complexidade social e a manutenção do equilíbrio entre eles. Daí porque também a relação entre os sistemas político e jurídico demandava não só a autonomia de cada um deles isoladamente considerado, mas também a estabilização de uma relação permanente que permitisse influências recíprocas. A Constituição forjada a partir das revoluções burguesas pretende oferecer à relação entre direito e política um mecanismo capaz de garantir interpenetrações permanentes e construtivas, sem deixar, contudo, que essas influências recíprocas corrompam a autonomia quer do direito, quer da política?

Com o florescimento da ideia moderna da Constituição, propõe-se uma inovadora relação de interdependência entre direito e política: de um lado, as decisões do sistema político estão subordinadas ao direito; de outro, o direito não pode prescindir da criação legislativa das normas jurídicas decorrente da deliberação política ${ }^{10}$. $\mathrm{O}$ vínculo criado

${ }^{7}$ NEVES, 2009, p. 19.

${ }^{8}$ NEVES, 2009, p. 34-35.

${ }^{9}$ Essa ideia é explicada por Marcelo Neves, com base em Luhmann, por meio da noção de que a Constituição realiza o acoplamento estrutural entre as esferas do direito e da política: "Esse acoplamento serviria à promoção e filtragem de influências recíprocas entre sistemas autônomos diversos, de maneira duradoura, estável e concentrada, vinculando-os no plano de suas respectivas estruturas, sem que nenhum desses sistemas perca a sua respectiva autonomia. Os acoplamentos estruturais são filtros que excluem certas influências e facilitam outras. Há uma relação simultânea de independência e de dependência entre os sistemas acoplados estruturalmente. As estruturas de um sistema passam a ser, mediante os acoplamentos estruturais, relevantes e mesmo indispensáveis à reprodução das estruturas de um outro sistema e vice-versa" (2009, p. 35).

${ }^{10}$ Nas palavras de Marcelo Neves, "se, de um lado, o direito é posto basicamente por decisões políticas, de outro, a diferença entre lícito e ilícito passa a ser relevante para os órgãos políticos supremos, inclusive para os procedimentos eleitorais de sua escolha" (2010, p. 205). Dieter Grimm lembra que a pergunta que as revoluções burguesas tiveram que responder estava em saber como a lei que emanava do processo político podia, ao mesmo tempo, vincular esse processo. Para Dieter Grimm, "[e]ste problema foi solucionado tomando-se a antiga ideia de hierarquia de normas (divina e secular) e reintroduzindo-a no direito positivo. Isso foi feito pela divisão do direito positivo em dois grupos diferentes: um que emanava ou era atribuído ao povo e regulava o governo, e um que 
entre o direito e a política não é apenas momentâneo ${ }^{11}$ : no Estado de Direito em que vige uma Constituição, a política produz o direito e o direito limita a política. A Constituição não exerce apenas uma função episódica de garantir trocas eventuais entre a política e o direito. O vínculo entre esses sistemas, assegurado pela Constituição, caracteriza-se por um mecanismo que "possibilita influências recíprocas permanentes entre direito e política, filtrando-as", ou, dito de outro modo, que garante a "interpenetração permanente e concentrada entre dois sistemas sociais autônomos, a política e o direito"12. A Constituição estabelece esse vínculo operacional permanente e dinâmico entre o direito e a política, possibilitando a influência recíproca entre ambos e potencializando as chances de aprendizado comum ${ }^{13}$.

\subsection{Constitucionalismo moderno: um movimento contra a}

\section{subordinação política do direito}

A Constituição alterou de forma radical o vínculo entre direito e política na medida em que o direito já não mais "se apresenta simplesmente como mecanismo de justificação do poder ou como instrumento de dominação, mas também serve à delimitação e ao controle do poder"14. A capacidade que o direito passa a apresentar de limitação e controle do poder é que permite compreender a razão pela qual a Constituição, em sentido moderno, angaria uma verdadeira pretensão normativa. Não há dúvida de que o surgimento do constitucionalismo passa pela ideia de blindagem funcional do direito à invasão total da política. O contexto histórico de florescimento do Estado de Direito está intimamente relacionado à consolidação de um mecanismo jurídico de controle do poder político. Era a submissão do Estado ao direito que estava em jogo. Afinal, os "súditos" já se submetiam amplamente ao direito - sobretudo nas relações horizontais privadas (no Estado absolutista) e nas relações travadas entre as camadas inferiores da sociedade e o detentor do poder (nas sociedades pré-modernas) -, mesmo antes da virada constitucionalista pós-revolucionária.

emanava do governo e regulava o povo. O primeiro regulamentou a produção e aplicação do segundo. O direito tornou-se reflexivo. Isto pressupôs, no entanto, que o primeiro tinha primazia sobre o segundo. Os teóricos revolucionários tinham uma noção clara desta consequência na elaboração da Constituição" (GRIMM, 2014, p. 56).

${ }^{11}$ Esses vínculos momentâneos são chamados pela teoria dos sistemas sociais de Luhmann de acoplamento operativo. (V. NEVES, 2010, p. 206.)

12 NEVES, 2010, 206.

${ }^{13} \mathrm{~A}$ teoria dos sistemas sociais de Luhmann denomina esse vínculo permanente de acoplamento estrutural, que constitui fundamentalmente mecanismo de interpretações concentradas e duradouras entre sistemas sociais. (NEVES, 2009, p. 37).

14 NEVES, 2010, p. 206. 
A novidade da Constituição, segundo Dieter Grimm, "reside no fato de que o poder estatal também se sujeita ao direito" ${ }^{15}$. Essa foi a grande mudança operada pela ideia de Constituição. Antes dela, "embora o Estado estivesse autorizado a definir juridicamente a conduta dos súditos a seu bel-prazer, ele próprio não estava sujeito a nenhuma vinculação jurídica" $^{\prime 16}$. O direito abandona a total opressão sofrida pela política no período das monarquias absolutistas e ganha autonomia para operar segundo seus próprios parâmetros de validade (lícito e ilícito segundo o sistema jurídico). A autonomia do direito em face da política depende da capacidade do direito de reagir, conforme seus próprios critérios e programas, à sobreposição negativa da política ${ }^{17}$. Isso significa dizer que a política provoca irritações, perturbações e surpresas no direito, mas este mantém sua capacidade de traduzir todas essas influências políticas em códigos jurídicos: "as ingerências da política no direito não mediatizadas por mecanismos especificamente jurídicos são excluídas" ${ }^{18}$.

A influência da política no direito não traduzida pela racionalidade jurídica fragiliza a autonomia do sistema jurídico na medida em que permite a sobreposição imediata do código da política (poder/nãopoder) ao código primário do direito (lícito/ilícito). Dá-se, nesse caso, a chamada corrupção do sistema jurídico pelo sistema político ${ }^{19}$. A noção de legalidade ou ilegalidade deixa de importar para a política, porque ela mesma encaminha, segundo seus próprios critérios, a decisão sobre a validade jurídica. Mesmo sabendo que a blindagem do direito contra pretensões totalitárias da política é uma questão típica do período das revoluções burguesas, sabe-se que até hoje é problematizada, notadamente em países que enfrentam, de forma mais intensa, o problema da exclusão social ${ }^{20}$.

No Brasil, como adverte Marcelo Neves:

determinados setores sociais têm forte probabilidade de não sofrer as sanções previstas na ordem jurídica, contando com a impunidade quando da prática de ilícitos penais; por outro, outros setores sociais são rigidamente

\footnotetext{
15 GRIMM, 2006, p. 70.

${ }^{16}$ GRIMM, 2006, p. 69.

${ }^{17}$ A esse respeito, Marcelo Neves explica que "o sistema jurídico assimila seletivamente, de acordo com os seus próprios critérios, os fatores do meio ambiente, não sendo diretamente influenciado por esses fatores. A vigência jurídica das expectativas normativas não é determinada imediatamente por interesses econômicos, critérios políticos, representações éticas, nem mesmo por proposições científicas (Luhmann 1990c; 1985), eis que depende de processos seletivos de filtragem conceitual no interior do sistema jurídico" (NEVES, 1996, p. 96).

18 NEVES, 2010, p. 207.

19 NEVES, 2009, p. 42.

20 NEVES, 1991, pp. 157-172.
}

Revista Publicum

Rio de Janeiro, Número 2, 2016, p. 74-111.

http://www.e-publicacoes.uerj.br/index.php/publicum

DOI: 10.12957/publicum.2016.23764 
subordinados às imposições restritivas, mas não dispõem de acesso a direitos básicos ${ }^{21}$.

Isso mostra como os códigos político e econômico podem se sobrepor às questões jurídicas, impossibilitando a construção da identidade do sistema jurídico. Nesse contexto, segundo Marcelo Neves, "não surge uma esfera de juridicidade apta a, de acordo com seus próprios critérios e de forma congruentemente generalizada, reciclar as influências advindas do seu contexto econômico e político" 22. Embora seja certo que o Brasil enfrenta, de modo mais grave, o problema da sobreposição do poder e do dinheiro ao direito quando comparado com a realidade de países que deram passos mais largos em termos de estágio civilizatório, não há dúvida de que temos avançado enormemente em direção à consolidação do Estado de Direito em nosso país. No campo da jurisdição constitucional, sobretudo em relação ao Supremo Tribunal Federal, há claros sinais de superação dos resquícios de subordinação do direito à política no período de vigência da atual Constituição.

Três observações podem ser feitas a propósito da garantia da autonomia do direito em relação à política na seara da jurisdição constitucional brasileira: (i) em primeiro lugar, é inegável que os Ministros do Supremo Tribunal Federal gozam da mais irrestrita independência, sendo mesmo considerado impensável, nos dias atuais, a aplicação de qualquer sanção ou represália de qualquer natureza ao juiz constitucional em razão das posições adotadas nas decisões que profere e nas deliberações judiciais ${ }^{23}$; (ii) o crescente controle da esfera pública em relação às decisões do Supremo Tribunal Federal impõe aos seus juízes um relevante ônus argumentativo na defesa das suas posições, o que inviabiliza qualquer tentativa de sobreposição da racionalidade política à jurídica, na medida em que eventuais ingerências políticas na interpretação e aplicação do direito pelo Tribunal devem necessariamente ser mediatizadas pelos mecanismos jurídicos; (iii) por fim, e especificamente quanto ao controle de constitucionalidade realizado pelo Supremo Tribunal Federal, não é possível antever problemas estruturais de corrupção do sistema jurídico pelo sistema político, tanto por não haver qualquer sinalização concreta de que o modo de indicação dos Ministros fragilize a independência da atuação judicial,

\footnotetext{
21 NEVES, 2010, p. 214.

22 NEVES, 1996, p. 99.

${ }^{23}$ Ver, sobre o ponto, Dieter Grimm: "A resposta à pergunta pela autonomia da jurisdição constitucional frente à política é dada pelo princípio da independência do juiz. Ele remete ao âmbito da ilegalidade todas as tentativas de se influenciar politicamente a interpretação e a aplicação do Direito vigente e proíbe a imposição de sanções a juízes devido a sua jurisdição, desde que não se façam culpados por prevaricação" (2006, p. 173).
} 
como por não termos experimentado na vigência da atual Constituição qualquer tentativa de ataque institucional à independência do Tribunal ${ }^{24}$.

Se não há riscos relevantes de rompimento da autonomia da esfera do direito pela política, sob o prisma das interferências externas ao Supremo Tribunal Federal ${ }^{25}$, eventuais riscos de autopolitização ${ }^{26}$ - pelo alinhamento voluntário de juízes constitucionais a programas partidários -, embora pouco relevantes no cenário brasileiro atual, poderiam ser minimizados por meio da melhoria das condições de deliberação no Tribunal. Não é de hoje que a doutrina vem manifestando críticas sobre o modo como as decisões são tomadas pelo Supremo Tribunal Federal: um amontoado disperso de visões particulares desprovido de debate efetivo entre os Ministros a propósito das posições declinadas por cada um nas sessões de julgamento ${ }^{27}$. É evidente que o fato de não haver uma discussão aberta e organizada a respeito dos fundamentos utilizados por cada Ministro ao apresentar o seu voto cria um espaço livre de constrangimentos para a inserção de argumentos diretamente vinculados à racionalidade política nos julgamentos do Tribunal. As propostas recentemente apresentadas pelo Ministro Luís Roberto Barroso ${ }^{28}$ podem contribuir de forma efetiva para superar as disfuncionalidades deliberativas atualmente enfrentadas: (i) limitar o reconhecimento da repercussão geral de matérias constitucionais ao número de casos que o Tribunal pode examinar no ano judiciário; (ii) instaurar debates prévios entre os Ministros a respeito dos casos que serão

\footnotetext{
${ }^{24}$ Rodrigo Brandão, depois de analisar com profundidade as formas de ataque institucional à Corte constitucional na experiência e na doutrina norte-americanas, afirma: "A recente retirada do jogo político de ataques institucionais à Suprema Corte deve ser comemorada como uma evolução da jovem democracia brasileira, como um passo importante na consolidação da independência judicial e do Estado de Direito no Brasil” (2011, p. 1454).

${ }^{25}$ Recente episódio da vida política nacional demonstrou que uma centelha de tentativa de constranger externamente o STF - exigindo, ainda que não de modo expresso, nova sabatina dos atuais Ministros do Tribunal que desejassem permanecer no cargo após os setenta anos de idade foi rapidamente declarada inconstitucional pelo próprio Tribunal, oportunidade em que se afirmou que "O princípio constitucional da separação dos Poderes (CRFB, art. 2º), cláusula pétrea inscrita no art. 60, § 4으, III, da Constituição República, revela-se incompatível com arranjos institucionais que comprometam a independência e a imparcialidade do Poder Judiciário, predicados necessários à garantia da justiça e do Estado de Democrático de Direito" (STF, ADI 5316 MC, Relator Min. Luiz Fux, julgado em 21/05/2015).

${ }^{26}$ Dieter Grimm alerta para o fato de que a utilização da jurisdição constitucional para fins políticos não pode ser sobrestimado. O princípio de independência do juiz "constitui-se apenas em um pressuposto, mas não em uma garantia de autonomia jurídica na aplicação do Direito. Ele protege um Tribunal que está disposto a não se submeter a eventuais influência políticas em sua jurisdição. Mas ele não protege contra uma autopolitização de tribunais constitucionais, cujos membros se formam seguindo, voluntariamente, linhas partidárias" (2006, p. 173).

27 Para entender de modo adequado os graves problemas deliberativos enfrentados atualmente pelo STF, ver o trabalho de Virgílio Afonso da Silva (SILVA, 2009,pp. 197 a 227).

28 V., por todos, entrevista divulgada na internet:
} http://mais.uol.com.br/view/1575mnadmj5c/gestao-de-processos-no-supremo-tem-de-mudar-dizbarroso-315-04024C9C396EE4B94326?types=A\&. 
discutidos no Plenário, divulgando-se, com antecedência mínima de trinta dias, os temas que serão enfrentados; (iii) exigir a circulação entre os Ministros, pelo menos uma semana antes da sessão de julgamento, da conclusão do voto do Ministro Relator do caso, de modo a possibilitar o efetivo debate sobre as principais questões do processo.

\subsection{O avanço do controle jurisdicional de constitucionalidade:}

\section{surgimento recente do risco de subordinação da política ao direito}

No título anterior, procurou-se demonstrar que, a despeito dos graves problemas de desigualdade social enfrentados em nosso país - alguns deles capazes de colocar em risco a própria autonomia do direito em face da política -, o Supremo Tribunal Federal não permite, sob a ótica institucional, a inserção direta dos códigos de poder político em suas decisões. Todas as interferências políticas no Tribunal são, regra geral, validamente traduzidas para os códigos que ordenam a racionalidade jurídica dos seus julgamentos. A certeza da independência do Tribunal em face de eventuais investidas políticas que busquem comprometer a imparcialidade dos seus julgamentos garante que as influências políticas - venham elas diretamente da esfera pública, ou sejam aquelas mediadas pelos representantes políticos da população -, todas elas sempre bem-vindas à jurisdição constitucional democrática e pluralista, serão revertidas para o discurso jurídico nos termos da sua própria racionalidade. Não está na pauta do dia, portanto, qualquer espécie de preocupação relevante com o rompimento da autonomia do direito pela política no campo da jurisdição constitucional brasileira, notadamente no âmbito do Supremo Tribunal Federal. Manifestações pontuais de descontentamento com supostos alinhamentos político-partidários de Ministros do Supremo, além de não terem comprovado fugas do referencial normativo da Constituição por parte de qualquer dos Ministros, não parecem sugerir qualquer fragilidade institucional do Tribunal e tampouco o comprometimento da independência e imparcialidade dos seus julgamentos.

Maior relevância no cenário nacional possui o candente debate sobre o risco de que os julgamentos realizados pelo Supremo Tribunal Federal impliquem em excessiva - e por isso indevida - subordinação da política ao direito. Antes de aprofundar o estudo sobre o tema, algumas advertências fazem-se necessárias. Em primeiro lugar, vale recordar que o surgimento do constitucionalismo moderno pretendia estancar a corrupção do sistema jurídico pelo político. As críticas atualmente dirigidas ao Supremo Tribunal Federal no sentido de que ele estaria a invadir a esfera política, roubando-lhe a cena, não revelam preocupação simétrica (mas com sinal invertido) àquela presente no nascimento do constitucionalismo. Isso porque não está em jogo o rompimento da autonomia da política 
pelo direito. As instituições políticas não foram em nenhum momento corrompidas pelo sistema jurídico. A autonomia da política em face do direito sempre esteve garantida no constitucionalismo moderno e contemporâneo, pois sempre revelou plena capacidade de reagir, conforme seus próprios critérios e programas, a eventuais tentativas de sobreposição negativa do direito.

Em segundo lugar, cabe esclarecer que, embora o direito não tenha gerado riscos relevantes de rompimento da autonomia da esfera política (ou sua corrupção sistêmica), pode-se identificar certa dificuldade do direito (e da jurisdição constitucional) em construir com a política relações capazes de gerar aprendizado e intercâmbio recíproco. 0 risco não é de rompimento dos códigos da racionalidade política pelos códigos da racionalidade jurídica, mas de uma deficiente capacidade de aprendizado demonstrada pelo direito em relação à política. Variados autores têm indicado esse autismo ${ }^{29}$ do direito em relação à política - revelador, em algumas ocasiões, de uma pretensão de expansão do direito sem reconhecimento da política ${ }^{30}$ - como o lado negativo da judicialização da política ${ }^{31}$, esta definida por Rodrigo Brandão como "processo de transferência do poder de tomar decisões sobre questões de alta conotação política dos detentores de mandatos eletivos (legisladores e chefes do executivo) para juízes" ${ }^{32}$. Sob esse prisma, o problema não está exclusivamente vinculado ao fenômeno da judicialização da política ${ }^{33}$ - este derivado de determinadas condições institucionais (fortalecimento do Judiciário e dos instrumentos de controle de constitucionalidade, previsão de direitos fundamentais) e

${ }^{29}$ A caracterização desse enfraquecimento dos entrelaçamentos entre os sistemas (jurídico e político) como autismo está presente na obra de Marcelo Neves, para quem essa característica de isolamento surge quando uma esfera de racionalidade perde a capacidade de aprendizado em relação a outra ou atua negativamente para o desenvolvimento desta. Esse excesso de preocupação com a consistência interna do próprio sistema (que se transforma em algo absoluto) desconsidera completamente a necessidade de adequação ao outro sistema com o qual se relaciona, tendendo, por isso, ao insulamento e à cristalização. O lado negativo desse autismo não se limita à estratificação do próprio sistema que se nega ao entrelaçamento produtivo com outro sistema. Há efeitos negativos também para o sistema que se relacionada com o autista: "[u]m sistema tem um certa incapacidade de, mediante entrelaçamentos, oferecer suas estruturas como critérios a serem incorporados construtivamente por um outro" (NEVES, 2009, p. 46). O fechamento cognitivo (para o aprendizado) de um sistema em face do outro acaba produzindo, a pretexto de elevar o grau interno de racionalidade, a uma irracionalidade decorrente da falta de capacidade de adequação externa ao ambiente no qual está inserido.

${ }^{30} \mathrm{~A}$ "expansão imperial" do direito ocorre quando esse sistema (jurídico), que dispõem de um código forte (constitucionalidade/inconstitucionalidade), ao relegar o outro (sistema político) à insignificância, não só prejudica as "pontes de transição", como também dificulta que os respectivos sistemas atuem adequadamente em relação à sociedade: um por força da tendência hipertrófica; ou outro, por força da propensão à atrofia. (V. NEVES, 2009, p. 47).

${ }^{31} \mathrm{~A}$ esse lado negativo da judicialização da política Teubner denominou processo de juridicização (TEUBNER, 2005).

32BRANDÃO, 2013, p. 177.

33 BARROSO, 2009, p. 71-91.

Revista Publicum

Rio de Janeiro, Número 2, 2016, p. 74-111.

http://www.e-publicacoes.uerj.br/index.php/publicum

DOI: 10.12957/publicum.2016.23764 
políticas (aceitação expressa ou tácita dos demais Poderes à expansão das competências do Judiciário $)^{34}$-, mas principalmente ao modo como os juízes, sobretudo os do Supremo Tribunal Federal, enfrentam essas questões políticas em suas decisões.

O fato de, nos últimos anos, o Tribunal ter recebido um número crescente de ações discutindo controvérsias de inegável natureza política não diz nada sobre como essas questões vêm sendo decididas. Como tem acentuado o Ministro Luís Roberto Barroso, a judicialização é um fato, o ativismo é uma opção, uma postura. Ser mais ou menos deferente aos outros Poderes, dialogar mais ou menos com os detentores de mandatos eletivos depende da maneira como o próprio Supremo Tribunal Federal responderá à crescente demanda institucional e social por respostas judiciais às mais variadas controvérsias da política nacional.

\subsection{A necessidade de reforçar a capacidade de aprendizado recíproco entre as esferas do direito e da política}

A autonomia que o constitucionalismo oferece aos sistemas jurídico e político não implica isolamento. Pelo contrário, a capacidade da Constituição para dar respostas adequadas à sociedade plural e multicêntrica depende em grande medida da aptidão que o direito e a política apresentam de se influenciarem reciprocamente numa relação horizontal de cooperação. As normas constitucionais oferecem algumas formas típicas de reingresso da política no direito: (i) produção de leis de acordo com o procedimento legislativo; e (ii) realização de reformas constitucionais limitadas temporal, formal e substancialmente pela própria Constituição. Esses são modelos típicos de ingresso da política no direito. O direito limita o poder político - na medida em que os atos deste decorrente estão sujeitos ao crivo da validade jurídica -, mas aquele reingressa no direito por meio da produção de normas jurídicas (legais e constitucionais). Há aqui uma relação de complementariedade e de tensão ${ }^{35}$. Podem-se questionar, em cada contexto específico, tanto os limites que o direito impõe à política quanto os limites do reingresso da política no direito.

34BRANDÃO, 2011, p. 180.

${ }^{35}$ Daniel Sarmento e Cláudio Souza Neto afirmam que a relação entre jurisdição constitucional e democracia envolve uma tensão sinérgica: "Há sinergia, porque o exercício adequado do controle de constitucionalidade pode proteger pressupostos necessários ao bom funcionamento da democracia, como as regras equânimes do jogo político e os direitos fundamentais. (...) Mas há também uma tensão potencial entre jurisdição constitucional e democracia. Se a imposição de limites para a decisão das maiorias pode ser justificada em nome da democracia, o exagero revela-se antidemocrático, por cercear em demasia a possibilidade do povo de se autogovernar. (SOUZA NETO, Claudio Pereira de; SARMENTO, Daniel, 2013, p. 137.)? 
Nesse contexto, parece claro que a Constituição não atua apenas como filtro de influências recíprocas entre direito e política, "mas também como instância da relação recíproca e duradoura de aprendizado e intercâmbio de experiências com as racionalidades particulares já processadas, respectivamente, na política e no direito" ${ }^{36}$. Dito de outro modo, "[a] Constituição estatal moderna surge como uma 'ponte de transição' institucional entre política e direito e, assim, serve ao desenvolvimento de uma racionalidade transversal específica, que impede os efeitos destrutivos de cada um desses sistemas sobre o outro e promove o aprendizado e o intercâmbio recíproco de experiências com uma forma diversa de racionalidade" ${ }^{37}$. Esse equilíbrio dinâmico envolve uma inescusável tensão entre as ideias de Estado de direito e de democracia. À Constituição incumbe imunizar o direito contra a ação parasitária da política e proteger a política contra a ação parasitária do direito, sem excesso de democracia em face do constitucionalismo e sem excesso de constitucionalismo em face da democracia. A aposta na capacidade de uma relação horizontal entre direito e política funda-se, no limite, na ideia de que, embora a tensão entre essas esferas nunca desapareça - senão desapareceria o próprio constitucionalismo -, é possível crer que o entrelaçamento entre direito e política possa contribuir para um projeto duradouro de fortalecimento da democracia ${ }^{38}$.

\section{O Supremo Tribunal Federal como mediador da conversação}

\section{entre direito e política}

De fato, a Constituição permite a troca contínua de influências recíprocas entre direito e política. Essa Constituição, que é direito de estatura superior, vincula igualmente a produção do direito de estatura inferior (produzido pelo Parlamento) e a aplicação do

\footnotetext{
36 NEVES, 2009, p. 62.

37 NEVES, 2009, p. 76.

${ }^{38}$ Nesse sentido, a valiosa síntese de Rodrigo Brandão, para quem a jurisdição constitucional, sem sobrepor o direito à política, pode desempenhar importante função relevante para a consolidação da democracia: "Sem dúvida que o reconhecimento por teorias empíricas de que o Judiciário não pode desempenhar uma postura messiânica de Guardião da Constituição - acima e para além da política e da opinião pública - deve levar a uma redução de expectativas quanto ao efetivo papel desempenhado pelo controle de constitucionalidade em uma democracia constitucional. Nada obstante, subsiste ao Judiciário uma função politicamente relevante. Já se salientou que o apoio difuso à independência judicial, que costuma existir em boa medida nas democracias constitucionais contemporâneas, garante-lhe um estoque de decisões contramajoritárias. Nesta esteira, o reconhecimento da influência da opinião pública sobre o controle de constitucionalidade não se incompatibiliza, antes estimula, a concepção de teorias prescritivas que se destinem a incitar o Judiciário a empregar a sua "cota de decisões contramajoritárias" para a tutela de direitos de minorias estigmatizadas, colocando-se à frente da opinião pública, tal como a Suprema Corte dos Estados Unidos o fez no caso Brown v. Board of Education". (BRANDÃO, 2011, p. 1489).
} 
direito (realizada pelo Judiciário). As transações registradas entre o ordenamento jurídico (esfera do direito) e as instâncias representativas do povo (esfera da política) são sempre mediadas pela Constituição, que permite e incentiva trocas de experiência e ao mesmo tempo expurga tentativas de sobreposição de uma esfera sobre a outra. A imagem de que o Supremo Tribunal Federal é o "guardião da Constituição" pode sugerir a impressão de que a ele cabe definir, por meio da interpretação do texto constitucional, os parâmetros da interlocução entre o direito e a política. É como se fosse possível afirmar uma lógica de exclusividade da definição dos termos em que o direito se relaciona com a política a partir do seguinte raciocínio "silogístico": (i) a Constituição tem a função de mediar as influências recíprocas entre direito e política, garantindo a autonomia de cada um e filtrando trocas de aprendizado; (ii) o Supremo Tribunal Federal tem a "função precípua" de guarda da Constituição; (iii) portanto, caberia ao Supremo Tribunal Federal definir, em última instância, o modelo de entrelaçamento do direito com a política.

Esse raciocínio seria procedente não fossem as seguintes objeções: (i) a função judicial de aplicação das leis - pela qual passa a competência do STF de guardar a Constituição - não transfere ao Judiciário a exclusividade da interpretação dessas normas; (ii) a Constituição, como médium de comunicação entre as esferas do direito e da política, é simultaneamente interpretada por todos os atores envolvidos nessa conversação; (iii) tanto o STF como o Congresso Nacional e o Presidente da República apresentam, cada um a seu modo, um entendimento sobre como a Constituição regula as transações recíprocas entre os sistemas jurídico e político em cada contexto específico. A Constituição não poderia exercer a contento a função de mediação dos sistemas se pertencesse - como objeto de sua propriedade - a um deles ${ }^{39}$. O sistema proprietário da Constituição poderia, sem maiores dificuldades, subordinar o outro, e, assim, a pretensão do constitucionalismo moderno de garantir autonomia e entrelaçamento dialógico entre o direito e a política ficaria gravemente comprometida.

Convém desconstruir, portanto, a noção de que a Constituição, ao regular normativamente o acoplamento dos sistemas jurídico e político, confere preferencial ou exclusivamente ao Poder Judiciário, e em especial ao Supremo Tribunal Federal, a tarefa de dizer por último o conteúdo e o tom da conversa entre esses sistemas. A Constituição dirige-se a ambos simultaneamente e estabelece parâmetros normativos de regulação das interpenetrações entre eles. Assim, não cabe nem ao direito nem à política afirmar, com exclusividade, os termos do diálogo. Cada um participa desse processo mediado

39 Marcelo Neves esclarece que "essa ambivalência da Constituição possibilita que ela possa ser vista tanto como instância do sistema político quanto como instituto do sistema jurídico" (2009, p. 58). 
constitucionalmente com o objetivo de, reproduzindo-se de modo coerente com os seus próprios códigos de racionalidade, influenciar o outro a prosseguir com o diálogo. Por isso que, funcionando a Constituição como mecanismo de comunicação duradoura entre direito e política, caberá tanto às instituições diretamente ligadas à esfera jurídica como também àquelas ligadas à esfera política funcionar, ao mesmo tempo, como interlocutoras e mediadoras desse diálogo.

\subsection{Um mediador posicionado em um dos lados: necessidade de} avaliação crítica das capacidades institucionais dos órgãos judiciais em

\section{face dos órgãos legislativos e executivos}

Na medida em que se reconhece que o Supremo Tribunal Federal não detém o monopólio da interpretação da Constituição e que nenhum dos atores envolvidos no diálogo entre direito e política conta com preferência apriorística na definição do modo como essa conversação deve ser produzida, pode-se também concluir que tanto as instituições encarregadas de aplicar o direito (no ápice das quais está o STF) como aquelas responsáveis pela produção política do direito (notadamente o Congresso Nacional) devem atentar para o fato de que não estão sozinhas ao tomar decisões, mas ao contrário participam de um empreendimento cooperativo no qual as interpretações do texto constitucional servem à reprodução da racionalidade daquele que fala e também à interlocução com a racionalidade daquele que escuta. Ao Supremo Tribunal Federal, nesse contexto, ao interpretar a Constituição, incumbe conferir integridade ao direito e manter aberto o canal de comunicação e aprendizado com a política. O equilíbrio dessas funções na jurisdição constitucional costuma ser objeto de análise jurídica a partir da tensão entre constitucionalismo (proteção de direitos) e democracia (soberania popular). Essa filtragem democrática da jurisdição constitucional, embora de extrema relevância, não resolve, por si só, todos os problemas do papel do Judiciário no desenvolvimento de estratégias dialógicas do direito com o sistema político.

O desenvolvimento de mecanismos de entrelaçamento entre o direito e a política necessários para a elevação das chances de aprendizado recíproco - depende do reconhecimento, por parte dos atores envolvidos, de que cada um é responsável pela função de interlocutor e de mediador desse processo de comunicação. A mediação é sempre realizada por um dos interlocutores, que estão posicionados em um dos lados do diálogo e, por isso mesmo, contribuem para a continuidade desse processo sob a óptica da sua própria racionalidade. Daí a necessidade de reconhecimento, pelos interlocutores, 
das limitações que cada sistema isoladamente considerado possui e das múltiplas possibilidades de crescimento e aprendizado proporcionado pelo diálogo entre esses interlocutores. Cada sistema (ou interlocutor) é dotado de inclinações específicas para contribuir, a partir da sua racionalidade (códigos de orientação), para o desenvolvimento de um empreendimento comum. Assim, a qualidade do diálogo depende, em certa medida, da capacidade que cada um possui de reconhecer, em si mesmo e no outro, virtudes e limitações.

Nesse campo, como lembra Daniel Sarmento, um ponto que publicistas brasileiros vêm negligenciando relaciona-se à necessidade de análise comparativa das capacidades institucionais de cada intérprete para a definição do seu papel na hermenêutica constitucional e dos métodos mais adequados para desempenhar tal mister ${ }^{40}$. Ainda segundo o mesmo autor, "a cegueira diante das capacidades institucionais dos intérpretes da Constituição pode gerar perspectivas hermenêuticas muito bonitas na teoria, mas que, quando aplicadas na prática, se revelem desastrosas para a própria concretização dos valores constitucionais" ${ }^{41}$.

A doutrina brasileira, só mais recentemente debruçada sobre a análise das capacidades institucionais no campo da interpretação constitucional ${ }^{42}$, tem alertado para a grande utilidade dessa análise como instrumento contrafático que indicará os limites funcionais da atuação dos órgãos administrativos, legislativos e judiciais. Na linha da advertência de Adrian Vermeule, o fator relacionado ao comprometimento com a democracia pode ser elemento excessivamente abstrato para justificar a opção institucional do intérprete adequado da Constituição ${ }^{43}$. Segundo essa perspectiva de análise, a distribuição de tarefas interpretativas entre diferentes instituições deve seguir o critério das suas capacidades institucionais, e não o do pedigree democrático dos órgãos estatais. Gustavo Binenbojm afirma que, nos campos em que, por sua alta complexidade técnica e dinâmica específica, falecem parâmetros objetivos para uma atuação segura do Poder Judiciário, a intensidade do controle deverá ser tendencialmente menor ${ }^{44}$. Não basta, portanto, discutir o problema da atividade desempenhada pelo STF a partir

40 SARMENTO, 2009, p. 312-313.

${ }^{41}$ SARMENTO, 2009, p. 313.

42 Gustavo Binenbojm afirma que, "apesar de a preocupação institucional já fazer parte da agenda de outros teóricos, é razoável sustentar que o trabalho que efetivamente deu corpo a esse debate foi o artigo de Cass Sunstein e Adrian Vermeule, publicado em 2003, intitulado Interpretation and institutions" (2008, p. 227).

43 VERMEULE, 2002.

44 BINENBOJM, 2008, p. 227.

Revista Publicum

Rio de Janeiro, Número 2, 2016, p. 74-111.

http://www.e-publicacoes.uerj.br/index.php/publicum

DOI: 10.12957/publicum.2016.23764 
exclusivamente da perspectiva democrática. Há problemas em relação aos quais os juízes padecem da necessária expertise e experiência para a tomada de decisão.

De fato, a defesa da ideia de que o Judiciário pode contribuir eficazmente para a proteção de direitos fundamentais e da consolidação das condições procedimentais da democracia não pode gerar o grave problema cunhado por Daniel Sarmento como idealização do Judiciário, esta identificada nas situações em que se afirmam "teorias que demandam algo que um juiz mediano não tenha como realizar" 45 . 0 autor então destaca três pontos que podem comprometer a capacidade dos juízes para a adoção de uma interpretação ótima da Constituição em certos contextos - e que, portanto, deveriam ser levados em conta por qualquer teoria prescritiva sobre a hermenêutica constitucional -, assim sintetizados: (i) a sobrecarga de trabalho ${ }^{46}$; (ii) a falta de conhecimentos técnicos fora do terreno do Direito ${ }^{47}$; e (iii) a lógica inerente ao processo judicial ${ }^{48}$. A visão conjunta desses fatores, permeada por uma atenção às capacidades institucionais dos juízes, pode recomendar, em determinados contextos, uma postura deferente do direito em relação à política.

No Brasil, na precisa observação de Daniel Sarmento, "as conhecidas mazelas do nosso Poder Legislativo tornam absolutamente injustificável qualquer confiança excessiva no processo político como meio de garantia da Constituição"49. A preocupação com a análise das capacidades institucionais dos órgãos estatais no contexto da realização do programa constitucional não derroga o impacto negativo da inércia dos poderes Legislativo e Executivo na fruição de direitos fundamentais. A experiência brasileira é farta em exemplos de bloqueios à realização de direitos fundamentais em virtude da omissão injustificada do legislador (direito à greve pelos servidores públicos, direito à igualdade na regulação da união civil entre pessoas do mesmo sexo, etc.). Desse modo, a análise das capacidades institucionais não impede a atuação do Supremo Tribunal Federal na concretização de direitos fundamentais, mas contribui para o reconhecimento de que a

45 SARMENTO, 2009, p. 313.

${ }^{46}$ A propósito desse ponto, afirma Daniel Sarmento: "[s]e os juízes têm uma infinidade de processos por dia, como ocorre no Brasil, evidentemente que não sobrará tempo e a energia indispensáveis para que cada um se engaje em procedimentos extremamente complexos para resolução de cada caso". (2009, p. 318).

${ }^{47}$ Sobre esse segundo ponto, Daniel Sarmento assevera que "[d]e modo geral, os juízes brasileiros estão bem aparelhados para o enfrentamento de questões jurídicas, mas quase nada sabem sobre outros campos do saber." (2009, p. 319).

48 Por fim, Daniel Sarmento destaca que os processos judiciais "foram pensados e estruturados com foco nas questões bilaterais de justiça comutativa, em que os interesses em disputa são apenas aqueles das partes devidamente representadas" e que a tomada de decisões que exige adequada visão de conjunto (em temas extremamente complexos) é muito difícil de se conseguir no âmbito da jurisdição. (2009, p. 319-320).

${ }^{49}$ SARMENTO, 2009, p. 320.

Revista Publicum

Rio de Janeiro, Número 2, 2016, p. 74-111.

http://www.e-publicacoes.uerj.br/index.php/publicum

DOI: 10.12957/publicum.2016.23764 
disciplina normativa exigida como condição para o exercício de direitos fundamentais pode demandar a participação dos Poderes Legislativo e Executivo, os quais dispõem de melhor aparelhamento para a tomada de decisões complexas de natureza técnica e econômica ${ }^{50}$.

É conhecida, entre nós, a grave objeção à formulação judicial de políticas públicas complexas, em relação às quais variáveis de ordem fática e econômica fogem quase que completamente ao campo de visão dos juízes ${ }^{51}$. Na síntese produzida pelo Ministro Luís Roberto Barroso, "temas envolvendo aspectos técnicos ou científicos de grande complexidade podem não ter no juiz de direito o árbitro mais qualificado, por falta de informação ou de conhecimento específico" ${ }^{52}$. Essa clivagem pragmática, aplicada à jurisdição constitucional, resulta na conclusão, veiculada por Vermeule, segundo a qual "a revisão judicial da constitucionalidade de textos legais e os processos decisórios judiciais destinados à interpretação constitucional devem ser realizados à luz das capacidades institucionais"53. Em síntese, a preocupação com a análise das capacidades institucionais condiciona o direito a criar vínculos operacionais de cooperação com a política, reconhecendo-lhe a preferência para a tomada de decisões que exijam profundo conhecimento sobre áreas não vinculadas ao sistema jurídico e seus códigos de orientação ${ }^{54}$. O Supremo Tribunal Federal, embora constitua a cúpula do sistema jurídico (direito), é responsável por mediar e fiscalizar as passagens entre direito e política ${ }^{55}$. É um mediador posicionado em um dos lados do diálogo e, justamente por isso, não deve hipertrofiar sua capacidade de contribuir, pela interpretação do direito, para a construção de soluções adequadas para a sociedade.

\subsection{Os riscos de um mediador autista: os monólogos}

\section{constitucionais do Supremo Tribunal Federal}

${ }^{50} \mathrm{Em}$ sua tese de titularidade, Daniel Sarmento volta ao tema para concluir que "o legislador tem, $a$ priori, uma capacidade institucional superior à do Poder Judiciário para avaliar quais políticas públicas voltadas à concretização do mínimo existencial são mais eficientes, considerando a relação entre o seu custo - não apenas no sentido econômico, mas também de geração de externalidades negativas - e o seu benefício" (SARMENTO, 2015, p. 222).

51 Para uma crítica pertinente a propósito do tema: SARMENTO, 2008, p. 533-586.

52 BARROSO, 2009.

53 VERMEULE, 2006. p. 230.

${ }^{54}$ Rodrigo Brandão alerta para o fato de que "é fundamental para a realização dos pressupostos do Estado Democrático de Direito um desenho institucional em que o sentido futuro da Constituição se dê através de um diálogo aberto entre as instituições políticas e a sociedade civil, em que nenhum deles seja 'supremo; , mas antes, que cada um dos 'poderes contribua com a sua específica capacidade institucional" (BRANDÃO, 2011, p. 287).

$55 \mathrm{Em}$ uma palavra: o Supremo Tribunal Federal atua como fiscalizador da legitimidade das passagens nos dois sentidos (direito > política e política > direito) dessa "ponte". 
A crítica que recentemente tem sido dirigida ao Supremo Tribunal Federal - ou pelo menos a algumas das suas decisões - é fruto de uma preocupação de certos setores de que o direito (especialmente o direito constitucional tal como interpretado pelo Judiciário) comprima excessivamente a política (e suas possibilidades de criação de normas jurídicas para concretizar a Constituição). Às vezes a crítica é fundamentada no princípio democrático, outras vezes na falta de capacidade institucional do Judiciário e outras até mesmo em uma idealização do legislador brasileiro. O fato é que se passou a discutir com vigor o problema concernente à possível falta de deferência do Supremo Tribunal Federal aos outros Poderes, notadamente ao Legislativo. Uma análise empírica da jurisprudência do Tribunal, entretanto, não revela um estado de coisas condizente com o tom de algumas críticas doutrinárias. Mas o risco de que a ascensão da jurisdição constitucional no Brasil conduza o Supremo Tribunal Federal a adotar uma postura de arrogância em relação aos outros Poderes não deve ser totalmente desprezado. A análise de alguns casos examinados pelo Supremo Tribunal Federal demonstra que a preocupação com um possível autismo judicial em face da política pode ser identificado, ainda que de forma pontual, na recente experiência da jurisdição constitucional brasileira.

Para iniciar essa análise, vale lembrar que o Supremo, ao julgar ação popular ajuizada para impugnar o ato por meio do qual o Presidente da República promoveu a demarcação da terra indígena "Raposa Serra do Sol", embora tenha rejeitado a pretensão de anular a demarcação contínua da reserva indígena, acolheu proposta do Ministro Menezes Direito no sentido de adicionar ao dispositivo da decisão dezoito cláusulas que deveriam condicionar futuras demarcações de terras indígenas. Essas cláusulas, posteriormente, foram objeto de deliberação do colegiado e resultaram nas dezenove "condicionantes" que constam do acórdão. O propósito de estabelecer, para o futuro, o regime jurídico do usufruto das terras indígenas ficou claro no voto do Ministro Menezes Direito $^{56}$. A solução de um caso concreto levou o Supremo a pretender fixar, sem a colaboração do legislador, um conjunto normativo extenso a propósito de um tema complexo e que demandaria a construção de consenso em torno de questões altamente controvertidas. À falta de legitimidade democrática do Judiciário para a tomada desse tipo de decisão soma-se, nesse caso, o déficit de capacidade institucional do STF para avaliar adequadamente as variáveis sociais, econômicas, políticas e culturais envolvidas.

${ }^{56}$ Esse voto, depois incorporado ao acórdão, contém a seguinte afirmação: "[a] partir da apreciação deste caso pude perceber que os argumentos deduzidos pelas partes são também extensíveis e aplicáveis a outros conflitos que envolvam terras indígenas. A decisão adotada neste caso certamente vai consolidar o entendimento da Suprema Corte sobre o procedimento demarcatório com repercussão também para o futuro. Daí a necessidade do dispositivo explicitar a natureza do usufruto constitucional e seu alcance". 
Em passado recente, no julgamento do Recurso Extraordinário n. 197.917, por meio do qual se discutia a constitucionalidade da fixação - em onze - do número de vereadores no Município de Mira Estrela, o Supremo Tribunal Federal estabeleceu, em abstrato, um padrão de fixação do número de vereadores em todo o país a partir de faixas populacionais por ele criadas $^{57}$. O suposto excesso de vereadores nos municípios brasileiros - mesmo que estabelecidos dentro das faixas admitidas pela Constituição levou o Supremo a estabelecer uma solução normativa geral que diminuísse o grau de discricionariedade dos municípios na escolha do número de vereadores. Nesse caso, o Tribunal desempenhou típica função normativa sem que o legislador fosse convidado a participar da construção da solução, complementando-a ou substituindo-a por outra em caráter definitivo.

Essas duas decisões do STF apresentam certas características comuns: (i) pretendem inovar na ordem jurídica a partir da inserção de novos parâmetros normativos com validade geral; (ii) criam regras jurídicas com base em princípios dotados de baixa densidade normativa; (iii) excluem o legislador do projeto de construção dessas normas; (iv) desconsideram a existência de outras possibilidades normativas (regras jurídicas) capazes de realizar igualmente os princípios constitucionais envolvidos; (v) rejeitam a opção de atribuir caráter transitório aos parâmetros normativos criados pelo Tribunal. Nos dois exemplos citados, diante de uma pluralidade de opções aptas a contribuir para a concretização dos princípios constitucionais envolvidos, o próprio STF escolheu aquela que considerou mais adequada, sem incitar o Poder Legislativo a participar desse empreendimento de construção de soluções normativas capazes de satisfazer as exigências constitucionais. O direito, nesses casos, perde a capacidade de aprendizado em relação à política ou atua negativamente para o desenvolvimento dessa. ${ }^{58}$

É verdade também que essas duas decisões - exemplos de monólogo judicial do STF - foram revertidas em momento posterior: (i) o precedente firmado no caso "Raposa Serra do Sol" foi corrigido pelo Tribunal, na parte em que pretendia criar uma pluralidade de regras jurídicas sobre o usufruto das terras indígenas, no julgamento dos embargos de declaração, ocasião em que se extirpou o trecho do acórdão que formava, sem qualquer participação do legislador, um estatuto do usufruto das terras indígenas; (ii) já o precedente por meio do qual o STF criou regras jurídicas que balizariam a fixação do número de vereadores por município acabou sendo superado pela aprovação de uma

${ }^{57}$ RE 197.917, Relator Min. Maurício Corrêa, Tribunal Pleno, julgado em 6/6/2002, DJ 7/5/2004.

58 Nessa hipótese, afirma Marcelo Neves, a prática constitucional passa a ser inadequada para a outra esfera (política) e para a sociedade em geral: "judiciário com pretensão de ocupar o espaço de legitimação da política" (2009, p. 76). 
Emenda à Constituição. A despeito da superação desses precedentes - frutos de uma falta de disposição para construção de uma relação produtiva de cooperação com o legislador , o fato é que, nessas situações, o STF hipertrofiou o sistema jurídico em detrimento do sistema político. Esses exemplos mostram como a jurisdição constitucional corre o risco de desprezar as capacidades de aprendizado recíproco entre direito e política, monopolizando, de forma autista, o espaço de criação de soluções que intensifiquem o nível de concretização das normas constitucionais.

O STF deve atentar para o fato de que, ao relegar a política à insignificância, não só prejudica a capacidade de aprendizado do direito em relação às instituições representativas, como também "dificulta que os respectivos sistemas [jurídico e político] atuem adequadamente em relação à sociedade" 59 . A postura autista do direito leva "a processos de autorregulação 'unidirecionais', incompatíveis com a heterogeneidade da sociedade" ${ }^{60}$, pois, apesar de prometer produzir, com seus meios, uma boa sociedade, só podem dar respostas parciais para o seu campo. A falta de disposição para "integrar-se construtivamente nos entrelaçamentos promotores de racionalidades transversais" prejudica "as outras esferas naquilo que elas poderiam prestar adequadamente à sociedade heterogênea" ${ }^{61}$. Felizmente, no caso brasileiro, não se pode identificar uma tendência à generalização - ou uma sequência de episódios contínuos - de imperialismo autista do direito, sobretudo da jurisdição constitucional, em relação à política. No entanto, também não se generalizou uma postura institucional do STF tendente a reforçar os entrelaçamentos promotores de intercâmbio e aprendizados recíprocos entre o direito e a política. A jurisdição constitucional brasileira, apesar de contar com episódios isolados de monólogos marcados pelo total desprezo pela política, não pode ser caracterizada como mecanismo produtor de um isolamento sistemático do direito em relação aos outros Poderes. Isso não significa, entretanto, que não haja muito a avançar no sentido de incrementar o grau de aprendizado e intercâmbio construtivo entre direito e política por meio do aperfeiçoamento do controle judicial de constitucionalidade.

\subsection{Diálogos institucionais e aprendizado recíproco: uma}

\section{preocupação recente do STF}

A Constituição atua como mecanismo realizador de múltiplas funções na relação entre direito e política: (i) diferencia funcionalmente um do outro; (ii) torna os códigos-diferença

\footnotetext{
59 NEVES, 2009, p. 47.

60 NEVES, 2009, p. 48.

61 NEVES, 2009, p. 48.
} 
(poder/não poder e lícito/ilícito) relevantes um para o outro; (iii) constrói uma relação duradoura de interpenetração (caracterizada pela complementação e pela tensão) entre eles; (iv) contribui para o incremento da capacidade de aprendizado recíproco entre ambos. O Supremo Tribunal Federal, a seu turno, atua como fiscalizador da legitimidade das passagens nos dois sentidos dessa "ponte" constitucional: do direito para a política e da política para o direito. As reações políticas às decisões dos tribunais constitucionais são fenômenos típicos das democracias contemporâneas. Consistem em formas de reingresso da política no direito. A experiência brasileira é farta em exemplos de reações políticas legítimas a decisões do Supremo Tribunal Federa ${ }^{62}$. Muitas delas, novamente confrontadas com a Constituição, foram consideradas legítimas pelo STF63.

A percepção crescente de que o STF não detém a última palavra na interpretação da Constituição ${ }^{64}$ possibilita ao próprio Tribunal antecipar reações políticas às decisões judiciais e atuar de antemão com maior grau de deferência aos demais atores institucionais. De fato, a relativa facilidade do processo de emenda constitucional no Brasil estimula que se responda ao ativismo judicial com ativismo legislativo. Nos mais de vinte seis anos de vigência da Constituição de 1988, já se contabilizou um número expressivo de emendas constitucionais superadoras de decisões de inconstitucionalidade do STF. Essa realidade deixa clara a necessidade de operar o sistema jurídico de modo a permitir contribuições políticas à concretização das normas constitucionais. O desprezo do direito pela política - naquilo que ela pode contribuir para a construção plural e democrática de soluções constitucionais - pode levar à intensificação das reações políticas às decisões judiciais do STF. Daí porque a capacidade - ainda que limitada - de antecipar possíveis reações políticas ao avanço do direito é extremamente útil na tomada de decisão quanto ao espaço decisório liberado pela própria jurisdição constitucional aos atores políticos ${ }^{65}$.

Para citar um exemplo de como a antecipação de reações políticas às decisões judiciais pode contribuir para aumentar a possibilidade de aprendizado recíproco entre

62 Para exemplificar: (i) aprovação da Lei n. 10.682/2002 - reconhecendo a prerrogativa de função aos ex-detentores de funções públicas - como reação ao julgamento da ADI 2.860; (ii) aprovação da Emenda Constitucional 29/2000 - permitindo a adoção de alíquotas progressivas para o IPTU como reação às decisões do STF que culminaram da aprovação da Súmula 668 do STF.

63 Pode-se citar como exemplo a decisão proferida pelo STF no julgamento da ADI 3.772, que considerou constitucional a Lei n. 11.430/2006, editada para superar o entendimento consolidado na Súmula 720 do STF.

${ }^{64}$ No Brasil, há dois trabalhos centrais que confirmam essa afirmação: MENDES, 2011; e BRANDÃO, 2011.

65 É sabido que as reações políticas ao STF podem afetar negativamente a sua imagem institucional. Por isso que o Tribunal tende a evitar o emprego desses métodos políticos de ataque à instituição ou às decisões por ele proferidas com vistas à sua autopreservação, de maneira a não raro se guiar por uma postura de "reação antecipada", na qual altera a sua preferência original para adequar-se a perspectiva aceitável pelos poderes políticos. (V. WHITTINGTON, 2003, p. 447.) 
direito e política, pode-se mencionar precedente ${ }^{66}$ por meio do qual o STF reconheceu ao Congresso Nacional a competência para interpretar o modo de realização das duas sessões deliberativas exigidas para aprovação de Emendas à Constituição. É possível que uma atuação mais enérgica do STF no controle da qualidade deliberativa no parlamento implicasse algum tipo de reação legislativa por parte do Congresso Nacional, circunstância em que parece ser mais prudente deferir ao órgão legislativo um espaço mais substancial de interpretação da norma constitucional. A opção pelo diálogo do STF com o Poder Legislativo parece ocorrer com maior frequência nos casos em que a intervenção judicial mais intensa (menos deferente) sugere maior probabilidade de algum tipo de reação política.

A ideia de incentivar os diálogos institucionais no campo da interpretação constitucional - o que contribui para a construção de uma relação equilibrada entre direito e política - tem sido defendida sistematicamente pelo Ministro Luís Roberto Barroso no Supremo Tribunal Federal com base na ideia central de que, "embora o Supremo Tribunal Federal seja o intérprete qualificado da Constituição, ele não precisa necessariamente dar sempre a última palavra", podendo fazer um apelo ao legislador, em certos casos, e, em outros, devolver a matéria ao Congresso Nacional ${ }^{67}$. O Ministro Luís Roberto Barroso recorda alguns exemplos importantes de recentes experiências de utilização do mecanismo de diálogo institucional no STF:

2. No julgamento de uma ação penal contra um Senador da República (AP 565, caso Ivo Cassol), colocou-se a questão da perda ou não do mandato. Não há nenhum sentido em um parlamentar condenado pelo STF a uma pena

66 STF, ADI 4.357, Relator Min. AYRES BRITTO, Relator p/ Acórdão: Min. LUIZ FUX, Tribunal Pleno, julgado em 14/3/2013: "Em suma, parece-me que esta Suprema Corte não pode se arvorar à condição de juiz da robustez do debate parlamentar para além das formas expressamente exigidas pela Constituição Federal. No que excede os limites constitucionais, há que se reconhecer uma espécie de deferência à atuação do Poder Legislativo no campo dos atos formais que se inserem no processo político, dotadas de um valor intrínseco pelo batismo democrático também no que concerne à interpretação da Constituição. É tênue, com efeito, o limite entre a defesa judicial dos valores da Constituição, missão irrenunciável deste Supremo Tribunal Federal por força da própria Carta de 1988 (CF, art. 102, caput), e uma espécie perigosa de supremacia judicial, através da qual esta Corte acabe por negar qualquer voz aos demais poderes políticos na construção do sentido e do alcance das normas constitucionais. Como aponta a moderna doutrina, "é fundamental para a realização dos pressupostos do Estado Democrático de Direito um desenho institucional em que o sentido futuro da Constituição se dê através de um diálogo aberto entre as instituições políticas e a sociedade civil, em que nenhum deles seja 'supremo', mas antes, que cada um dos 'poderes' contribua com a sua específica capacidade institucional” (BRANDÃO, 2011, p. 287).

67 V. resumo da palestra proferida pelo Ministro Luís Roberto Barroso no dia 17/9/2015, no Instituto Fernando Henrique Cardoso. Disponível em: http://www.migalhas.com.br/Quentes/17,MI225392,41046-

Constituicao+Direito+e+politica+por+Luis+Roberto+Barroso. 
grave não ter como consequência a perda do cargo. É assim com todos os demais cidadãos. Porém, a Constituição, por disposição expressa, prevê que cabe à Casa Legislativa decidir a respeito. É péssima a previsão constitucional. O intérprete constitucional pode em certos casos até ser criativo, mas não pode torcer o sentido mínimo das palavras. Ao votar no caso, eu fiz um apelo ao Congresso que emendasse a Constituição, para reparar essa incongruência. Não pelo meu apelo, que eu não tenho essa pretensão, mas pela lógica do argumento, o Senado Federal, pouco tempo depois, aprovou a emenda constitucional alterando a redação do dispositivo. Falta votar na Câmara.

3. Alguns outros exemplos em que propus que a matéria fosse devolvida ao Congresso:

a) Na modulação dos efeitos da decisão que considerou inconstitucional a emenda que previa o pagamento dos precatórios em 15 anos - eu não estava no Tribunal quando o caso foi julgado, só participei da modulação - eu propus um modelo alternativo para o pagamento de precatórios, para viger a partir do exercício seguinte, caso o Congresso não optasse por disciplinar a matéria de modo diferente. No fundo, qual foi o meu raciocínio: o Congresso já havia tentado por duas vezes disciplinar a questão dos precatórios e o Supremo derrubou. Acho que nós tínhamos o dever de dizer o que considerávamos adequado. Foi o que eu fiz. Na votação final, em uma solução de compromisso, alguns dos pontos que eu propus foram aceitos $e$ encarregou-se o CNJ de regulamentar;

b) No julgamento de desaposentação (desaposentação é a situação do trabalhador que se aposenta por tempo de contribuição e depois volta ao mercado de trabalho e contribui mais alguns anos e quer renunciar à primeira aposentadoria para ficar com a segunda) eu disse: a matéria não é disciplinada na legislação. Há uma lacuna. Eu proponho a seguinte solução, para vigorar daqui a 180 dias, a menos que o Congresso disponha de maneira diversa. ${ }^{68}$

Nos exemplos acima mencionados pelo Ministro Luís Roberto Barroso, o reconhecimento de que o direito não pode tomar para si o monopólio da interpretação constitucional - em especial nos casos em que lacunas normativas são preenchidas temporariamente pelo STF para garantir a eficácia de normas constitucionais - conduz ao

68 V. resumo de palestra proferida pelo Ministro Luís Roberto Barroso disponível em http://www.migalhas.com.br/Quentes/17,MI225392,41046Constituicao+Direito+e+politica+por+Luis+Roberto+Barroso.

Revista Publicum

Rio de Janeiro, Número 2, 2016, p. 74-111.

http://www.e-publicacoes.uerj.br/index.php/publicum

DOI: 10.12957/publicum.2016.23764 
incremento do diálogo com a política na construção de soluções cooperadas em relação às quais prevalecem a ótica do respeito mútuo e do aprendizado recíproco ${ }^{69}$.

\section{Construindo "pontes de transição" entre direito e política} por meio da jurisdição constitucional

Sem desprezar o relevante papel que o STF pode desempenhar - tal como tem feito - na garantia dos direitos fundamentais e dos pressupostos da democracia, "cumpre valorizar o constitucionalismo que se expressa fora das cortes judiciais, em fóruns como os parlamentos e nas reivindicações da sociedade civil que vêm à tona no espaço público informal"70. A crise de representatividade do Poder Legislativo nos dias atuais não pode obscurecer a percepção de que "a política, com todas as suas imperfeições, pode e deve ser um campo aberto ao debate constitucional, inspirando-se também por princípios e não apenas por preferências ideológicas ou por interesses de facções" ${ }^{71}$. De fato, "não há solução para os problemas nacionais que não passe pelo resgate da política, seja na esfera institucional da atividade parlamentar, seja no campo informal das mobilizações da cidadania"72.

O paradoxo (ou tensão) entre o jogo democrático e o Estado de direito, ainda que não possa ser solucionado definitivamente, "é suscetível de ser controlad[o] e solucionad[o] nos casos concretos de emergência de conflitos entre a racionalidade jurídica e a política"73. Exatamente nesse contexto mostra-se fundamental o papel dos tribunais constitucionais:

além de sua função de filtragem seletiva de influências e irritações, eles servem ao bom funcionamento da Constituição como 'ponte de transição' entre racionalidades diversas. De certa maneira, pode-se dizer que eles atuam como fiscalizadores da legitimidade das passagens nos dois sentidos dessa 'ponte' (...) $)^{74}$

\footnotetext{
${ }^{69}$ Nas palavras do Ministro Luís Roberto Barroso, "[e]sta fórmula dos diálogos institucionais constitui uma alternativa ao modelo de supremacia judicial. Acho que com um pouco mais de maturidade institucional e prática, ela pode ser, em muitos casos, o caminho ideal" (V. resumo de palestra proferida pelo Ministro Luís Roberto Barroso disponível em: http://www.migalhas.com.br/Quentes/17,MI225392,41046-

Constituicao+Direito+e+politica+por+Luis+Roberto+Barroso.)

70 SOUZA NETO, Claudio Pereira de; SARMENTO, Daniel, 2013, p. 159.

71 SOUZA NETO, Claudio Pereira de; SARMENTO, Daniel, 2013, p. 160.

72 SOUZA NETO, Claudio Pereira de; SARMENTO, Daniel, 2013, p. 160.

73 NEVES, 2009, p. 77.

74 NEVES, 2009, p. 77.

Revista Publicum

Rio de Janeiro, Número 2, 2016, p. 74-111.

http://www.e-publicacoes.uerj.br/index.php/publicum

DOI: 10.12957/publicum.2016.23764
} 
Os tribunais constitucionais podem contribuir para o controle e a solução casuística da tensão entre direito e política, desde que compreendam que a sua atuação deve buscar a promoção do aprendizado e o intercâmbio recíproco de experiências entre os sistemas jurídicos e político ${ }^{75}$. A qualidade do entrelaçamento entre direito e política - ou entre Estado de direito e democracia - depende, em certo grau, da desenvoltura dos tribunais constitucionais para estabelecer um canal de comunicação claro, eficiente e aberto com as instituições representativas do povo. Daí a exigência de aprofundar o estudo sobre as técnicas decisórias adotadas pelo STF, pois é por meio delas que ele escolhe o modo como pretende dialogar com as instituições políticas.

\subsection{A escolha das técnicas decisórias na jurisdição constitucional a} partir dos interlocutores preferenciais do STF: um modelo incentivador do diálogo

A escolha dos métodos adotados pelo STF para incrementar o diálogo institucional em torno da interpretação das normas constitucionais depende de uma avaliação quanto ao grau de eficácia do emprego das técnicas decisórias colocadas a sua disposição. A opção entre apelar ao legislador ou criar uma solução normativa transitória para regular determinadas relações jurídicas até que sobrevenha a intervenção legislativa, por exemplo, deve ser feita à luz da experiência institucional acumulada a partir do relacionamento entre as decisões tomadas pelo STF e as respectivas respostas legislativas.

No Brasil, a técnica da declaração de inconstitucionalidade sem pronúncia de nulidade foi pouco utilizada na jurisprudência do Supremo Tribunal Federal, talvez porque a disciplina legislativa nessa hipótese continua vigente, a despeito do apelo para sua modificação contido na decisão, contexto no qual provavelmente o legislador tradicionalmente pouco atento às decisões do Tribunal - não se sente pressionado a promover as alterações legislativas necessárias. O receio da produção do vácuo normativo indesejável - fundamento último da utilização da técnica da inconstitucionalidade sem pronúncia de nulidade - gera um efeito dúplice: (i) a manutenção da vigência da disciplina inconstitucional; e (ii) a diminuição da carga obrigacional dirigida ao legislador para

75 A superioridade normativa das teorias dialógicas foi sintetizada por Rodrigo Brandão nos seguintes termos: "a grande vantagem da teoria dos diálogos constitucionais consiste em reconhecer as falhas e as virtudes de cada ator institucional, confiando que a interação entre eles em um sistema de separação de poderes contribuirá para a construção de um sistema deliberativo melhor" (2011, p. 288). 
realização das modificações necessárias na disciplina normativa considerada inconstitucional.

Pode-se também citar no Brasil a escassa eficácia persuasiva dos monitos (ou apelos) ao legislador. O Supremo Tribunal Federal fixou prazo de sessenta dias para que fosse ultimado o processo legislativo de regulamentação do parágrafo $3^{\circ}$ do artigo $8^{\circ}$ do Ato das Disposições Constitucionais Transitórias ${ }^{76}$. O Congresso Nacional não observou a recomendação do Tribunal, conduzindo-o a qualificar a norma constitucional como de eficácia plena, a despeito da falta de regulamentação ${ }^{77}$. Há muitos exemplos de não acolhimento pelo Congresso e pelo Presidente da República dos apelos feitos pelo Supremo Tribunal Federal: (i) não elaboração de lei de revisão geral anual da remuneração dos servidores públicos federais ${ }^{78}$; (ii) não edição de lei complementar regulamentando o direito de greve pelos servidores públicos ${ }^{79}$; (iii) falta de regulamentação do artigo 18 , $\S$ 4ํㅡ, da Constituição, que versa a criação de novos municípios, em desrespeito à ordem de legislar expedida em julgamento de ação direta de inconstitucionalidade ${ }^{80}$.

A maior utilização da técnica decisória consistente em modular os efeitos temporais da pronúncia de inconstitucionalidade sugere a estabilização, no âmbito da Corte, de uma percepção de que a superação de vácuos normativos pelo Congresso Nacional, quando realizada, depende de um grande lapso temporal ${ }^{81}$. Não parece demasiado assinalar que a maior colaboração do Parlamento com a Corte tem ocorrido

\footnotetext{
${ }^{76}$ STF, MI 283, Relator Min. Sepúlveda Pertence, Tribunal Pleno, julgado em 20/3/1991,DJ 14/11/1991 $77 \mathrm{Em}$ precedente do ano de 1994, o STF reconheceu a inércia do Congresso no cumprimento da obrigação de legislar fixada em precedente do ano de 1991: "O prazo fixado, no julgamento do Mandado de Injunção n. 283, para o cumprimento do dever constitucional de editar essa regulamentação de há muito se escoou sem que a omissão tenha sido suprida. Não há, pois, razão para se conceder novo prazo ao Congresso Nacional para o adimplemento desse seu dever constitucional, impondo-se, desde logo, que se assegure aos impetrantes a possibilidade de ajuizarem, com base no direito comum, ação de perdas e danos para se ressarcirem do prejuízo que tenham sofrido" (STF, MI 447, Relator Min. Moreira Alves, Tribunal Pleno, julgado em 5/5/1994, DJ 1/7/1994).

78 STF, ADI 2.061, Relator Min. Ilmar Galvão, Tribunal Pleno, julgado em 25/4/2001, DJ 29/6/2001.

79 STF, MI 20, Relator Min. Celso de Mello, Tribunal Pleno, julgado em 19/5/1994, DJ 22/11/1996.

80 STF, ADI 3.689, Relator Min. EROS GRAU, Tribunal Pleno, julgado em 10/5/2007, DJe-047 DIVULG 28/6/2007 PUBLIC 29/6/2007 DJ 29/6/2007 PP-00022 EMENT VOL-02282-04 PP-00635.

81 Essa percepção foi expressamente confessada pelo Supremo Tribunal Federal em julgamento assim ementado: "PARTIDO POLÍTICO - FUNCIONAMENTO PARLAMENTAR - PROPAGANDA PARTIDÁRIA GRATUITA - FUNDO PARTIDÁRIO. Surge conflitante com a Constituição Federal lei que, em face da gradação de votos obtidos por partido político, afasta o funcionamento parlamentar $e$ reduz, substancialmente, o tempo de propaganda partidária gratuita e a participação no rateio do Fundo Partidário. NORMATIZAÇÃO - INCONSTITUCIONALIDADE - VÁCUO. Ante a declaração de inconstitucionalidade de leis, incumbe atentar para a inconveniência do vácuo normativo, projetando-se, no tempo, a vigência de preceito transitório, isso visando a aguardar nova atuação das Casas do Congresso Nacional" (ADI 1.351, Relator Min. Marco Aurélio, Tribunal Pleno, julgado em 7/12/2006, DJ 30/3/2007).
} 
em temas de maior relevância política - senão mesmo eleitoral ${ }^{82}$-, o que põe em dúvida, em certo sentido, a importância da técnica decisória adotada pela Corte para a obtenção de uma resposta do legislador.

O fato é que no Brasil, como em outros quadrantes, a ampliação da tipologia das decisões no controle de constitucionalidade - chegando até as soluções aditivas ${ }^{83}$ (criadoras de novos segmentos normativos não referíveis a qualquer texto normativo existente na ordem jurídica) - "parece inspirada especialmente pela exigência de não produzir vácuos no ordenamento jurídico, acrescida e dramatizada pela efetiva inércia do legislador, o qual realmente, a mais das vezes, tem não só tolerado, mas também favorecido a obra de suplência da Corte" ${ }^{84}$. A impressão de um legislador pouco atento às solicitações dirigidas pela Corte foi um dos fatores catalizadores da assunção pelo Supremo Tribunal Federal de uma função normativa. No caso brasileiro, a falta de resposta do legislador tem sido considerada importante elemento legitimador da atividade de criação de normas jurídicas pelo Tribunal.

Depois de uma série de precedentes que declararam a mora do legislador em definir as possibilidades e condições para o exercício do direito de greve por servidores públicos civis $^{85}$, e considerando a insistência da inércia do legislador, o Supremo Tribunal Federal resolveu adotar uma solução normativa de modo a regulamentar o direito constitucional cuja eficácia estava interditada pela mora legislativa ${ }^{86}$. 0 direito à percepção de aviso prévio proporcional ao tempo de serviço teve a eficácia garantida por meio de sentença normativa do Supremo Tribunal Federal ${ }^{87}$ mais de duas décadas depois do primeiro reconhecimento da mora legislativa no setor específico ${ }^{88}$. Esses exemplos confirmam o acerto da proposta doutrinária do Ministro Luís Roberto Barroso no sentido de que, embora a fronteira entre direito e política possa encontrar dificuldade de demarcação, a atuação do Supremo Tribunal Federal poderá ser mais ou menos deferente

82 É o que se passou, por exemplo, com a aprovação da Lei Complementar 135 de 2010 (Lei da Ficha Limpa), após o julgamento do STF que reconheceu a necessidade de lei complementar para cuidar das hipóteses de inelegibilidade. (Cf. ADPF 144, Relator Min. Celso de Mello, Tribunal Pleno, julgado em 6/8/2008, DJe 25/2/2010.)

${ }^{83} \mathrm{~V}$. o meu estudo sobre o tema (SOUSA FILHO, 2016).

${ }^{84}$ Tradução livre de “(...) sembraispiratasoltantoall'esigenzadi non produrrevuotinell’ordinamento, accresciuta e drammatizzatadall' effettivainerziadellegislatore, ilqualeaddirittura, ilpiùdelle volte, ha non solo tollerato, maanche favorito, l'operadi 'supplenza' della Corte." (MODUGNO, 1981, p. 1651). ${ }^{85}$ STF, MI 20/DF, Rel. Min. Celso de Mello, DJ 22/11/1996; STF, MI 585/TO, Rel. Min. Ilmar Galvão, DJ 2/8/2002; e STF, MI 485/MT, Rel. Min. Maurício Corrêa, DJ 23/8/2002.

${ }^{86}$ STF, MI 670, Relator Min. Maurício Corrêa, Relator p/ Acórdão: Min. Gilmar Mendes, Tribunal Pleno, julgado em 25/10/2007, DJe 30/10/2008.

87 STF, MI 943, Relator Min. Gilmar Mendes, Tribunal Pleno, julgado em 6/2/2013, DJe 30/4/2013.

88 STF, MI 369, Relator Min. Néri da Silveira, Relator p/ Acórdão: Min. Francisco Rezek, Tribunal Pleno, julgado em 19/8/1992, DJ 26/2/1993. 
à política, a depender da existência ou não de uma atuação prévia do Legislativo ou do Executivo em relação ao tema: (i) em caso positivo, o Judiciário deve ser, em regra, deferente para com as escolhas razoáveis feitas pelos agentes políticos; (ii) em caso negativo - os órgãos cujos membros têm o batismo da representação popular não atuaram -, a lacuna no ordenamento deve ser superada pelo Judiciário, que não pode deixar de decidir as questões alegando a omissão normativa ${ }^{89}$.

A pouca atenção do legislador aos apelos incentivou a Corte constitucional italiana a incrementar o uso da técnica da sentença aditiva de princípio. Por meio da adoção desse tipo de decisão, o Tribunal pretende assegurar a discricionariedade legislativa e, ao mesmo tempo, contornar as graves consequências advindas da inércia do legislador. Com efeito, a Corte, mediante esse tipo de pronúncia, exprime a declaração de ilegitimidade constitucional de uma omissão legislativa - consistente na ausência de previsão, da parte da norma de lei reguladora de um direito constitucionalmente garantido, de um mecanismo idôneo a assegurar a efetividade deste - e deixa ao legislador a competência para introduzir a disciplina faltante, mas, ao mesmo tempo, prescreve um princípio ao qual o juiz comum é habilitado a fazer referência para superar a omissão inconstitucional pela via da individualização da regra nos casos concretos ${ }^{90}$. Essa técnica decisória oferece interessante possibilidade de estabelecimento de um diálogo produtivo com o legislador, sem deixar que a eventual inércia dos órgãos legislativos implique um bloqueio total à eficácia da norma constitucional.

A análise da experiência acumulada no Brasil a respeito da eficácia das técnicas decisórias no tocante à ativação do diálogo com o Poder Legislativo sugere que os apelos ao legislador desprovidos de outras medidas que garantam a imediata eficácia da norma constitucional não costumam gerar incentivos à cooperação do Congresso Nacional com o STF. A falta de consequências diretamente extraídas da decisão do Tribunal tem gerado, nos últimos anos, uma clara apatia do Legislativo em colaborar com os chamamentos judiciais ao diálogo institucional. Daí a constrição à inovação nesse campo. A escolha das técnicas decisórias utilizadas pelo STF no âmbito da jurisdição constitucional deve mirar o incremento do diálogo entre direito e política a partir dos resultados práticos que cada modelo decisional gerou na experiência acumulada até o presente momento. As chamadas "chances de aprendizado" ${ }^{91}$ entre os Poderes podem ser incrementadas pelo

${ }^{89}$ BARROSO, 2013, p. 45-60.

${ }^{90}$ ANZON, 1992, p. 3213.

${ }^{91}$ A categoria foi criada por Marcelo Neves sob confessada inspiração na qualidade de abertura cognitiva da teoria dos sistemas de Luhmann. (2010, p. 203-222.)

Revista Publicum

Rio de Janeiro, Número 2, 2016, p. 74-111.

http://www.e-publicacoes.uerj.br/index.php/publicum

DOI: 10.12957/publicum.2016.23764 
uso adequado das técnicas decisórias, notadamente, como será tratado no próximo tópico, das sentenças aditivas.

\subsection{Uma recente "ponte de transição" engendrada pelo STF: as} sentenças aditivas como mecanismo de aperfeiçoamento do diálogo entre direito e política

A qualidade do diálogo institucional entre Corte constitucional e legislador depende, em grande medida, da correção das técnicas decisórias utilizadas pela Corte, especialmente das sentenças aditivas - estas criam normatividade para evitar vácuos normativos perigosos ${ }^{92}-$, em relação às quais a possibilidade de concorrência no exercício de função normativa pode implicar irritações mútuas de grande importância para o aperfeiçoamento da democracia e para a efetividade dos direitos fundamentais. O reconhecimento de que não há contradição apriorística entre direitos fundamentais e democracia não necessariamente acarreta a aceitação de uma estrutura institucional que atribua ao Judiciário a última palavra sobre a melhor forma de - por meio da regulamentação concretizá-los. Ao contrário, consciente de que a função normativa judicial constitui o exercício de uma competência de suplência, o Judiciário deve desempenhá-la sob a advertência de que a norma, por ele produzida, tem natureza precária e transitória, cedendo imediatamente ante o advento da norma legislativa.

O Ministro Marco Aurélio, no julgamento do Mandado de Injunção n. 943, alertou para a necessidade de que a decisão aditiva formulada pelo Supremo Tribunal Federal explicitasse a condição resolutiva da solução normativa consistente na edição de regulamentação constitucional por parte do Congresso Nacional. Naquela oportunidade, caracterizou a sentença aditiva como "uma decisão submetida a uma condição resolutiva, porque, vindo a lei, o pronunciamento judicial deixa de surtir eficácia. Quando atuamos de forma concreta, desafiamos os representantes do povo e dos Estados a legislarem a respeito". A norma criada pelo Judiciário - tenha ou não a sentença estabelecido um prazo de vigência do regime provisoriamente fixado pelo Supremo Tribunal Federal - será automaticamente afastada pela superveniência de nova disciplina normativa criada pelo

$92 \mathrm{Em}$ obra específica sobre o tema, afirmei que "as sentenças de perfil aditivo produzem norma jurídica na medida em que identificam (ou criam) norma não referível a uma disposição normativa específica, constituindo, desse modo, espécie de integração do ordenamento jurídico". Concluí, nesse sentido, que "as sentenças aditivas realizam típica operação de integração do ordenamento jurídico por meio de criação de um novo segmento normativo com o objetivo de superar um estado de omissão inconstitucional (lacuna normativa indesejável capaz de produzir resultados normativos inconstitucionais)". (SOUSA FILHO, 2016, p. 257-258). 
legislador para regular a matéria. A advertência é útil, pois a atividade normativa desempenhada pelo Judiciário não deve ser interpretada, de modo algum, como interdição da competência do Congresso Nacional de regulamentar, a qualquer momento - e de forma diversa -, o setor normativo que padecia de omissão legislativa. O objetivo da Corte constitucional é iniciar um diálogo explícito com os poderes Executivo e Legislativo acerca da regulamentação de direitos fundamentais ${ }^{93}$. A norma elaborada pelo Judiciário - em especial pelo STF - revela explícita propensão à transitoriedade, na medida em que se destina à substituição por uma disciplina normativa produzida pelas instâncias políticas preferenciais. Em recente julgamento no STF, o Ministro Luís Roberto Barroso defendeu o uso moderado da função normativa judicial como forma de aperfeiçoar o diálogo institucional com o Parlamento:

O sistema aqui proposto destina-se a ocupar provisoriamente uma lacuna
constitucional terrivelmente ameaçadora. Não em perspectiva, mas
comprovada por um quadro de inconstitucionalidade grave e sistemática que
já se estabilizou. Como referido, esse tipo de providência já foi implementado
por esta Corte em outras ocasiões, acompanhado de uma exortação ao
Congresso Nacional para que se debruce sobre a questão. No presente caso,
o regime a ser imposto começará a produzir efeitos apenas em 2015, de
modo que o legislador disporá de cerca de um ano para aprofundar a
reflexão que já vem conduzindo e, se for o caso, introduzir modelo alternativo
que seja igualmente eficaz. Longe de menosprezar a separação dos Poderes,
a fórmula de que se cogita tem o objetivo de promover o diálogo institucional
na matéria - não em abstrato, e sim em torno de medidas efetivas para o
restabelecimento da normatividade constitucional grosseiramente violada. ${ }^{94}$

A solução normativa engendrada pelo Supremo Tribunal Federal, além de transitória, não deve optar pela estratégia perfeccionista de extrair o maior grau de proteção possível do direito materialmente fundamental ameaçado pelo vácuo normativo. A função normativa deve ser exercida pelo STF de modo a promover a menor intervenção possível no ordenamento jurídico, com o único objetivo de superar o vácuo normativo que impede a eficácia das normas constitucionais fundamentais. A criação normativa de natureza judicial deve ser aquela suficiente e necessária a superar o estado de omissão

${ }^{93}$ Forte corrente doutrinária, no Brasil, bem representada por Rodrigo Brandão, da Universidade do Estado do Rio de Janeiro, defende o incremento de diálogo institucional tendente à superação do vácuo normativo (BRANDÃO, 2011).

${ }^{94}$ STF, QO na ADI 4.357 e na ADI 4.425, voto proferido em 19/3/2014, Rel. Min. Luiz Fux. 
inconstitucional, tornando eficaz a norma constitucional com a menor intromissão possível no ordenamento jurídico ${ }^{95}$. O legislador certamente poderá, com base na formulação de juízos dotados de grande carga de discricionariedade, incrementar o grau de proteção dos direitos fundamentais em jogo, oferecendo aos destinatários da disciplina legal algo a mais do que recomenda o mínimo de proteção aquém do qual se pode vislumbrar uma omissão inconstitucional.

O legislador deve encarar a sentença aditiva como o (re)início de uma rodada de diálogo constitucional voltada especificamente à efetivação de direitos fundamentais e, portanto, à constante manutenção e revitalização das condições de realização da democracia. A solução normativa adotada pelo STF não tem pretensão de definitividade e, por isso, não deve conduzir à paralisação das discussões no espaço público e no Parlamento. Ao contrário, deve funcionar como propulsora de um maior comprometimento das instâncias decisórias do Estado com a garantia dos direitos inalienáveis da pessoa humana, sem os quais o Estado Democrático de Direito não se realiza efetivamente.

A criação de normas jurídicas pelo STF deve funcionar como mecanismo de fomento ao diálogo rápido e contínuo entre os poderes Judiciário, Executivo e Legislativo. Uma produtiva cadeia de diálogo pode instaurar-se a partir do impulso gerado pela criação de normas transitórias pelo Judiciário. A norma ao final produzida pelo legislador -

${ }^{95}$ No mesmo sentido, a lição de Mortati, tal como explicitada por Fernández Segado: "Admite Mortati que los resultados alcanzados por el intérprete em su actividad de integración no son equiparables a aquellos que puedan derivarse de la intervención del legislador, por el hecho de que el juez constitucional le está vedado todo criterio de oportunidad acerca del mejor modo de conseguir la máxima satisfacción de los intereses constitucionalmente protegidos, 'dovendos ilimitare ad estrarre dal complessivo sistema legislativo, interpretato alla luce delle direttive della Costituzione, la regola che valga a dare a queste al meno um mínimo di attuazione'. Mantenida en tales límites, concluirá el granius publicista italiano, la operación desarrollada por el juez constitucional no podrá considerarse invasiva de la discrecionalidaddel legislador encuanto que aquél 'si limita a dichiarare (sia pure conquel margine di creatività insita (...) in ogni operazione alla lacuna, sul la base del grado di affinità del rapporto da regolare con altrigià disciplinati" " (SEGADO, Francisco Fernández. La Justicia Constitucional: una visión de derecho comparado. Tomo I (Los sistemas de Justicia Constitucional, las 'dissentig opinions' el control de las omisiones legislativas, el control de 'comunitariedad'). Madrid: Dykinson-Constitucional, 2009. p. 575). Na doutrina brasileira, Marinoni afirma com precisão: "Frise-se que a decisão a respeito de como um dever de tutela deve ser cumprido é, antes de tudo, questão afeta ao Parlamento. Quando o legislador viola um direito fundamental na sua função de mandamento de tutela, cabe ao Judiciário assegurar o adequado grau de tutela do direito fundamental. Não obstante, o problema está na circunstância de que a ação do juiz, diante da falta da lei, não tem a mesma elasticidade ou a mesma latitude da ação do legislador. Para ser mais claro: o legislador tem ampla esfera de liberdade para a definição da providência ou do meio para a tutela do direito fundamental, enquanto o juiz, exatamente por não ter a mesma latitude de poder do legislador, deve atuar apenas para garantir que o dever de proteção satisfaça as exigências mínimas na sua eficiência. Assim incumbe ao juiz atuar de modo a impor não mais que o mínimo necessário à proteção do direito fundamental" (MARINONI, 2013, p. 21).

Revista Publicum

Rio de Janeiro, Número 2, 2016, p. 74-111.

http://www.e-publicacoes.uerj.br/index.php/publicum

DOI: 10.12957/publicum.2016.23764 
muitas vezes a partir da iniciativa do poder Executivo - constituirá o resultado de uma cadeia dialógica provida de grande capacidade de aperfeiçoamento do processo decisório. O reconhecimento judicial de que a norma criada para efetivar o direito fundamental possui caráter transitório, precário e minimalista constitui uma atitude de indução do Congresso Nacional ao prosseguimento no processo de regulamentação do direito fundamental em jogo ${ }^{96}$. O incentivo ao diálogo institucional dar-se-ia, de acordo com a concepção do Ministro Luís Roberto Barroso, em torno de medidas efetivas para o restabelecimento da normatividade constitucional violada pela omissão inconstitucional. Essa ideia revela uma faceta democratizante da técnica decisória aditiva a partir da indução da regulação normativa pelo Congresso Nacional ${ }^{97}$.

A experiência acumulada pelo STF nos últimos anos sugere que a construção de estratégias dialógicas de relacionamento com os outros Poderes depende de uma mescla criativa de técnicas decisórias capaz de incitar a participação política na construção de soluções adequadas às controvérsias constitucionais complexas e garantir um grau mínimo de eficácia imediata de direitos fundamentais. Para tanto, a denominada sentença aditiva plúrime (ou de princípio com regra) pode contribuir enormemente. Esse modelo decisório tem espaço em casos excepcionais nos quais a Corte introduz, ao lado de um princípio não autoaplicativo, uma das suas possíveis especificações - portanto uma regra que valerá transitoriamente e de forma subsidiária (porque cederá à futura regulamentação legislativa). Essa técnica rompe com uma tradicional lógica de funcionamento das sentenças aditivas, pois, mesmo na reconhecida falta de uma única solução normativa capaz de concretizar a norma constitucional, a Corte supre diretamente a lacuna jurídica indesejável por meio da adição de uma regra concretizadora do princípio indicado ao legislador como vetor material da norma a ser futuramente produzida. Dessa forma, a Corte constitucional, de um lado, indica o princípio não autoaplicativo que dever guiar o legislador na disciplina da matéria; e, de outro, oferece, desde logo, uma das

${ }^{96}$ Essa atitude baseada na comunicação rápida e contínua entre poderes, bem como a de autocontenção e expressa delegação de campos normativos ao parlamento foi definida por Mark Tushnet como managerial model (modelo diretivo). (TUSHNET, 2008, p. 12).

${ }^{77}$ Daniel Sarmento lembra, a propósito da judicialização de prestações estatais ligadas ao mínimo existencial, que "o recurso a técnicas jurisdicionais flexíveis e dialógicas constitui alternativa importante, preferível tanto à omissão judicial quanto a um ativismo de resultados duvidosos. 0 Judiciário pode destravar bloqueios políticos e sociais existentes no equacionamento de certos temas, conferindo visibilidade a questões importantes ligadas ao mínimo existencial e forçando os demais poderes a agir, sem, no entanto, apresentar soluções prontas para problemas altamente complexos, que muitas vezes ele não teria condições de elaborar a contento" (SARMENTO, 2015, p. 241-242). 
soluções compatíveis com aquele princípio, tolhendo o impacto jurídico que decorreria da ausência de disciplina normativa autoaplicativa ${ }^{98}$.

Essa técnica de decisão não é totalmente nova na nossa experiência jurisprudencial. Afinal, o Ministro Luís Roberto Barroso tem procurado associar apelos para que o legislador crie regras jurídicas a partir dos princípios constitucionais indicados pelo STF à criação imediata de regras jurídicas válidas transitoriamente até que sobrevenha a decisão política de criação definitiva do direito. É o que se viu no julgamento da questão da desaposentação e do regime constitucional de precatórios. Em ambas as situações, o Ministro incentivou o diálogo com o Congresso Nacional - por meio do apelo ao legislador marcado por recomendações normativas de caráter principiológico - e ao mesmo tempo estabeleceu um parâmetro normativo que valeria imediatamente até que sobreviesse a norma criada pelo Poder Legislativo. Na arguição de descumprimento de preceito fundamental por meio da qual se pretendeu o reconhecimento de que o sistema prisional brasileiro revelava verdadeiro estado de coisas inconstitucional, vários pedidos de natureza aditiva ${ }^{99}$ foram deduzidos com o objetivo de incentivar o diálogo e a cooperação entre os poderes e de equacionar o grave problema de sistemática violação aos direitos fundamentais dos presos no Brasil.

\section{Conclusão}

Não há necessidade de resenhar, à guisa de conclusão, todos os argumentos apresentados neste artigo, o que seria enfadonho. Não custa lembrar, entretanto, que a Constituição consubstancia o mecanismo por meio do qual o direito e a política se mantêm

\footnotetext{
${ }^{98} \mathrm{~A}$ doutrina, atenta ao risco de subversão do princípio da preferência do legislador, faz as seguintes advertências quanto ao uso da técnica: (i) a excepcionalidade do contexto, ou seja, o risco de uma lesão grave e irreparável a uma norma constitucional; e (ii) a natureza subsidiária e transitória da regulamentação de detalhamento, válida apenas até que sobrevenha a intervenção reparadora do legislador (PANZERA, 2013, p. 167-168.)

99 Vale destacar, por todos, os seguintes pedidos de natureza aditiva deduzidos na ADPF 347: (i) determinação aos juízes e tribunais brasileiros que passem a considerar fundamentadamente 0 dramático quadro fático do sistema penitenciário brasileiro no momento de concessão de cautelares penais, na aplicação da pena e durante o processo de execução penal; (ii) afirmação de que o juízo da execução penal tem o poder-dever de abrandar os requisitos temporais para a fruição de benefícios e direitos do preso, como a progressão de regime, o livramento condicional e a suspensão condicional da pena, quando se evidenciar que as condições de efetivo cumprimento da pena são significativamente mais severas do que as previstas na ordem jurídica e impostas pela sentença condenatória, visando assim a preservar, na medida do possível, a proporcionalidade e humanidade da sanção; (iii) reconhecimento de que o juízo da execução penal tem o poder-dever de abater tempo de prisão da pena a ser cumprida, quando se evidenciar que as condições de efetivo cumprimento da pena foram significativamente mais severas do que as previstas na ordem jurídica e impostas pela sentença condenatória, de forma a preservar, na medida do possível, a proporcionalidade e humanidade da sanção. (Cf. inicial da ADPF 347: http://jota.info/wpcontent/uploads/2015/05/ADPF-347.pdf).
} 
entrelaçados e capazes de trocar experiências. O aprendizado recíproco entre essas esferas exige o constante esforço de criação, manutenção e revisão de "pontes de transição" que permitam esse intercâmbio recíproco de experiências. O Supremo Tribunal Federal, embora constitua a cúpula do sistema jurídico (direito), é responsável por mediar e fiscalizar as passagens entre direito e política. Daí porque deve cuidar para que a interpretação constitucional por ele realizada contribua para a intensificação do diálogo institucional, evitando monólogos autistas, prejudiciais à efetivação das normas constitucionais.

O desenvolvimento de mecanismos de entrelaçamento entre o direito e a política necessários para a elevação das chances de aprendizado recíproco - depende da capacidade que cada sistema (direito e política) possui de reconhecer em si mesmo e no outro, virtudes e limitações. A ideia de capacidades institucionais pode auxiliar o STF a perceber que o diálogo entre direito e política pode ser mais produtivo na medida em que ele reconheça que a sua falta de expertise para enfrentar integralmente determinados problemas pode ser compensada pela cooperação e pelo aprendizado com os outros Poderes. A qualidade do diálogo institucional depende, não há dúvida, da qualidade da comunicação estabelecida entre os interlocutores. E a melhoria das condições comunicacionais da relação entre o STF e os outros Poderes exige a utilização de técnicas decisórias capazes de incitar a conversação entre esses atores institucionais e permitir a imediata concretização de direitos fundamentais. As técnicas decisórias devem ser utilizadas de modo a garantir um espaço relevante de construção normativa por parte do Legislativo, sem deixar de lado a necessidade, muitas vezes, iminente, de conferir eficácia às normas constitucionais por meio da própria decisão proferida.

Nesse sentido, a preocupação demonstrada pelo Ministro Luís Roberto Barroso no sentido de que o sistema jurídico não pode tomar para si o monopólio da interpretação constitucional - em especial nos casos em que lacunas normativas são preenchidas temporariamente pelo STF para garantir a eficácia de normas constitucionais - conduz ao incremento do diálogo construtivo com a política, na construção de soluções cooperadas,em relação às quais, prevalecem a ótica do respeito mútuo e do aprendizado recíproco. Para tanto, a sentença aditiva - quando utilizada com parcimônia - pode servir como mecanismo frutífero de indução ao diálogo institucional, pois, ao mesmo tempo que estabelece um canal claro de comunicação com o legislador por meio de apelos específicos, cria parâmetros normativos transitórios capazes de conferir eficácia imediata às normas constitucionais e também de incentivar a colaboração célere do Congresso Nacional. 


\section{Bibliografia}

ANZON, Adele. Nuovetecnichedecisoriedella corte costituzionale. In: Giurisprudenzacostituzionale, v. 37, n. 4, p. 3199-3217, iuglio/ag. 1992.

BARROSO, Luís Roberto. A Constituição brasileira de 1988: 25 anos de vida. In: Reflexões sobre a Constituição: uma homenagem da advocacia brasileira. Brasília: Alumnus: OAB, Conselho Federal, 2013, p. 45-60.

BINENBOJM, Gustavo. Uma Teoria do Direito Administrativo. 2a ed. Rio de Janeiro: Renovar, 2008.

BRANDÃO, Rodrigo. Diálogos Constitucionais nos Estados Unidos e no Brasil. RJLB, Ano 1 (2015), n. 4.

Supremacia Judicial v. Diálogos Constitucionais: a quem cabe a última palavra sobre o sentido da Constituição? Rio de Janeiro: Lumen luris, 2012.

GRIMM, Dieter. Constituição e política. Belo Horizonte: Del Rey, 2006.

A conquista do constitucionalismo e suas perspectivas em um mundo mudado. Tradução de Cláudia Rentroia. Tratado de direito constitucional. Rio de Janeiro: Elsevier, 2014, v. 2.

MARINONI, Luiz Guilherme. Do controle da insuficiência de tutela normativa aos direitos fundamentais processuais. In: Revista de processo, v. 38, n. 226, p. 13-29, dez. 2013.

MENDES, Conrado Hubner. Direitos Fundamentais, Separação de Poderes e Deliberação. São Paulo: Saraiva, 2011.

MODUGNO, Franco. La funzione legislativa complementar edella corte costituzionale. In: Giurisprudenza costituzionale, v. 26, n. 8/10, p. 1646-1664, 1981.

NEVES, Marcelo. Luhmann, Habermas e o Estado de Direito. Lua Nova, n. 37, 1996, p. 93106.

. Transconstitucionalismo. São Paulo:Martins Fontes, 2009.

Estado Democrático de Direito e Constitucionalismo na América do Sul.In: PIOVESAN, Flavia; BOGDANDY, Armin von; ANTONIAZZI, Mariela Morales (Orgs.). Direitos Humanos, Democracia e Integração Jurídica na América do Sul. Rio de Janeiro: Lumen Juris, 2010, p. 203-222.

“A Crise do Estado: Da Modernidade Central à Modernidade Periférica - Anotações a partir do Pensamento Filosófico e Sociológico Alemão", in: Anais do 16o Congresso dos Tribunais de Contas do Brasil (10 a 14 de novembro de 1991), vol. 1, Recife: Tribunal de Contas do Estado de Pernambuco, pp. 157-172.

PANZERA, Claudio. Interpretare manipolare combinare: una nuova prospettiva per lo Studio delle decisioni della Corte costituzionale- Napoli: Edizioniscientificheitaliane, 2013.

SARMENTO, Daniel. Interpretação Constitucional, Pré-compreensão e Capacidade Institucional do Intérprete. In: Cláudio Pereira de Souza Neto, Daniel Sarmento e Gustavo 
Binenbojm (coord.). Vinte Anos da Constituição Federal de 1988. Rio de Janeiro: Lumen Juris, 2009, p. 311-322.

. A Proteção Judicial dos Direitos Sociais: Alguns Parâmetros ÉticoJurídicos. In: SOUZA NETO, Cláudio Pereira de; SARMENTO, Daniel. (Orgs.). Direitos Sociais: fundamentos, judicialização e direitos sociais em espécie. Rio de Janeiro: Lumen Juris, 2008, p. 533-586.

SILVA, Virgílio Afonso da. (2006) O STF e o controle de constitucionalidade: deliberação, diálogo e razão pública.Revista de Direito Administrativo no 250. Rio de Janeiro: FGV Direito Rio. pp. 197 a 227.

SOUSA FILHO, Ademar Borges de. Sentenças aditivas na jurisdição constitucional brasileira. Belo Horizonte: Fórum, 2016.

SOUZA NETO, Claudio Pereira de; SARMENTO, Daniel. Notas sobre jurisdição constitucional e democracia: A questão da "última palavra" e alguns parâmetros de autocontenção judicial. In: Constitucionalismo e democracia. Salvador: JusPodivm, 2013.

TEUBNER, Gunther. El derecho como sistema autopoiético de la sociedad global / Gunther Teubner; Carlos Gómez-Jara Díez, editor. Bogotá: Universidade Externado de Colômbia, 2005.

TUSHNET, Mark .Weak Courts, Strong Rights. Judicial Review and Social Welfare Rights in Comparative constitutional Law. New Jersey: Princeton University Press, 2008.

VERMEULE, Adrian. Judicial Review and Institutional Choice.William and Mary Law Review Vol. 43 (4), 2002.

WHITTINGTON, Keith E., Legislative Sanctions and the Strategic Environment of Judicial Review. I-Con: The International Journal of Constitutional Law, Vol. 1, July 2003. 